\title{
Population Genomics of Yams: Evolution and Domestication of Dioscorea Species
}

\author{
Yu Sugihara, Aoi Kudoh, Muluneh Tamiru Oli, Hiroki Takagi, \\ Satoshi Natsume, Motoki Shimizu, Akira Abe, Robert Asiedu, Asrat Asfaw, \\ Patrick Adebola, and Ryohei Terauchi
}

\begin{abstract}
Yam is a collective name of tuber crops belonging to the genus Dioscorea. Yam is important not only as a staple food crop but also as an integral component of society and culture of the millions of people who depend on it. However, due to its regional importance, yam has long been regarded as an "orphan crop" lacking a due global attention. Although this perception is changing with recent advances in genomics technologies, domestication processes of most yam species are still ambiguous. This is mainly due to the complicated evolutionary history of Dioscorea species caused by frequent hybridization and polyploidization, which is possibly caused by dioecy that imposed obligate outcrossing to the species of Dioscorea. In this chapter, we provide an overview of the evolution of Dioscorea and address the domestication of yam from population genomics perspectives by
\end{abstract}

Yu Sugihara and Aoi Kudoh contributed equally to this work.

Y. Sugihara $\cdot$ A. Kudoh

Laboratory of Crop Evolution, Graduate School of Agriculture, Kyoto University, Kyoto, Japan

M. T. Oli

Iwate Biotechnology Research Center, Kitakami, Iwate, Japan

Department of Animal, Plant, and Soil Sciences, School of Life Sciences, La Trobe University, Melbourne, VIC, Australia

H. Takagi

Iwate Biotechnology Research Center, Kitakami, Iwate, Japan

Ishikawa Prefectural University, Nonoichi, Ishikawa, Japan

S. Natsume $\cdot$ M. Shimizu $\cdot$ A. Abe

Iwate Biotechnology Research Center, Kitakami, Iwate, Japan

R. Asiedu · A. Asfaw · P. Adebola

International Institute of Tropical Agriculture (IITA), Ibadan, Nigeria

R. Terauchi $(\bowtie)$

Laboratory of Crop Evolution, Graduate School of Agriculture, Kyoto University, Kyoto, Japan

Iwate Biotechnology Research Center, Kitakami, Iwate, Japan

e-mail: terauchi@ibrc.or.jp

Om P. Rajora (ed.), Population Genomics: Crop Plants,

Population Genomics [Om P. Rajora (Editor-in-Chief)],

https://doi.org/10.1007/13836_2021_94, (C) The Author(s) 2021 
focusing on the processes of hybridization and polyploidization. A review is given to the recent population genomics studies on the hybrid origin of D. rotundata in West and Central Africa, the global dispersion of D. alata through human migrations, and the whole-genome duplication of the South America species of D. trifida. In the end, we give a summary of current understanding of sex-determination system in Dioscorea.

Keywords Dioecy - Dioscorea - Domestication · Evolution · Genetic diversity · Hybridization · Polyploidy $\cdot$ Population genomics · Sex determination · Yam

\section{Introduction}

Yam is a collective name of tuber crops belonging to the genus Dioscorea. In 2018, the global yam production was around 72.6 million tons (FAOSTAT 2018). The major yam species include Dioscorea rotundata, D. alata, D. trifida, D. polystachya, and D. esculenta (Arnau et al. 2010). White Guinea yam (D. rotundata) is the most important yam worldwide, mainly grown in West and Central Africa, especially Côte d'Ivoire, Ghana, Togo, Benin, Nigeria and Cameroon, the region known as the "yam belt", which accounts for $\sim 92.5 \%$ of the total world yam production (FAOSTAT 2018). Yam is a staple crop in many tropical countries, and it also plays important roles in society and culture of the people in the major yam-growing regions (Coursey 1972; Obidiegwu and Akpabio 2017; Obidiegwu et al. 2020). However, due to its localized importance, yam has been regarded as an "orphan crop" and received considerably less research attention compared to the major crop species.

The genetic improvement of yam is urgently needed for the food security of yam-growing regions, but it is constrained by various abiotic and biotic factors (Mignouna et al. 2003). For example, the entire genus Dioscorea is characterized by dioecy, with male and female flowers borne on separate individuals, which imposes obligate outcrossing to the species in the genus. Due to its dioecy, farmers clonally propagate yams to maintain its germplasms, and true seeds are rarely used as the starting materials for planting. However, this clonal propagation reduces the genetic diversity, which causes the vulnerability to plant diseases. Also, the clonal propagation causes the difficulty of purging deleterious mutations from the germplasms like in cassava (Ramu et al. 2017). To achieve effective yam improvement by overcoming these constraints, we need to answer key questions in yam genetics and genomics including: (1) what is the genetic relationships between cultivated yams and their wild relatives, and how the domestication of yam happened? (2) how to deploy Dioscorea genetic diversity to improve agronomic traits of cultivated yams? (3) how dioecy of Dioscorea is genetically controlled and how we can manipulate it to make an efficient cross breeding? Thanks to the recent development of genome sequencing technologies, we can now address these questions using 
population genomics approaches. In this chapter, we review the latest findings of the domestication of yam from population genomics perspectives.

\section{The Genus Dioscorea: Its Origin and Botanical Characteristics}

The genus Dioscorea, which consists of approximately 630 species, is the largest one in the family Dioscoreaceae of monocotyledons (WCSP 2020). It is widely distributed in the tropical and temperate regions and occurs in diverse environments from forests to grasslands (Wilkin et al. 2005; Maurin et al. 2016; Viruel et al. 2016). Several studies have been conducted on the phylogenetic relationships of species in Dioscorea. Previously, intrageneric taxa have been proposed based on morphological characters (Uline 1898; Knuth 1924; Prain and Burkill 1936, 1939; Burkill 1960; Huber 1998). However, diagnostic keys and delineation of taxa varied according to the authors. Recently, phylogenetic analyses have been conducted based on chloroplast DNA (cpDNA) sequences and nuclear gene sequences (for review, see Noda et al. 2020). Noda et al. (2020) provided a large-scale phylogenetic tree containing 183 species and proposed dividing Dioscorea into two subgenera (Dioscorea and Helmia), with 11 major clades and 27 sections/species groups.

Dioscorea likely originated in the Laurasian Palaearctic between the Late Cretaceous and the Early Eocene (Fig. 1). In the Eocene and Oligocene, Dioscorea expanded to the southern region by long-distance dispersal or migration by land bridges. In the Oligocene and Miocene, main Dioscorea lineages experienced divergence events on a worldwide scale. In the Miocene and Pliocene, some lineages dispersed into new areas. The number of biogeographical speciation events seems to have decreased after the Quaternary period began (Maurin et al. 2016; Viruel et al. 2016; Couto et al. 2018).

The majority of Dioscorea species are perennial herbaceous climbers with simple or compound leaves and reproduce sexually and/or clonally (Fig. 2). Flowers in Dioscorea are mostly dioecious with male and female flowers borne on separate individuals, and multiple sex-determination systems were reported in the genus (see Table 2 and Sect. 6). Most species produce winged seeds and capsular, six-seeded fruits, while some species have wingless seeds, samaroid or berry fruits (Caddick et al. 2002; Noda et al. 2020). In addition to sexual reproduction, Dioscorea species propagate clonally by bulbils, rhizomes, or tubers. Bulbils are aerial tubers that are formed in the axils of leaves or bracts of some Dioscorea species (Fig. 2f). They are mainly consumed as food, but also used as folk medicine in many cultures (Ikiriza et al. 2019). Bulbils are generally brown-colored and have small tubercles over their surface, but their shape and size vary in the different species (Murty and Purnima 1983). D. bulbifera (also known as aerial yam) is the major bulbil-producing species and is characterized by considerable bulbil shape diversity (Terauchi et al. 1991). 

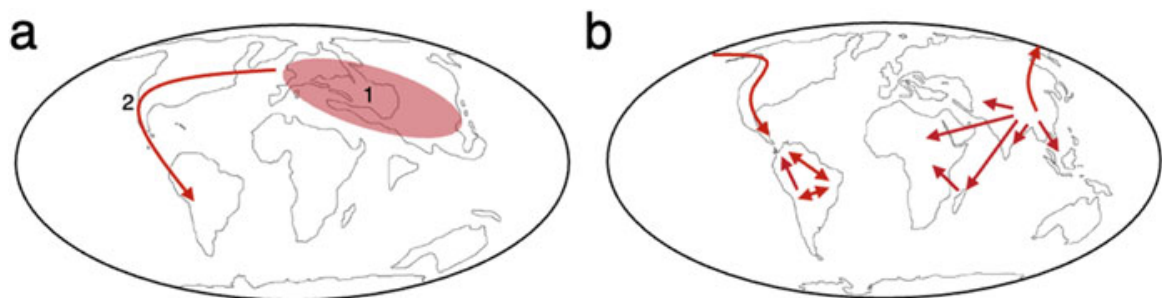

Early Eocene - Early Oligocene

Early Oligocene - Late Miocene
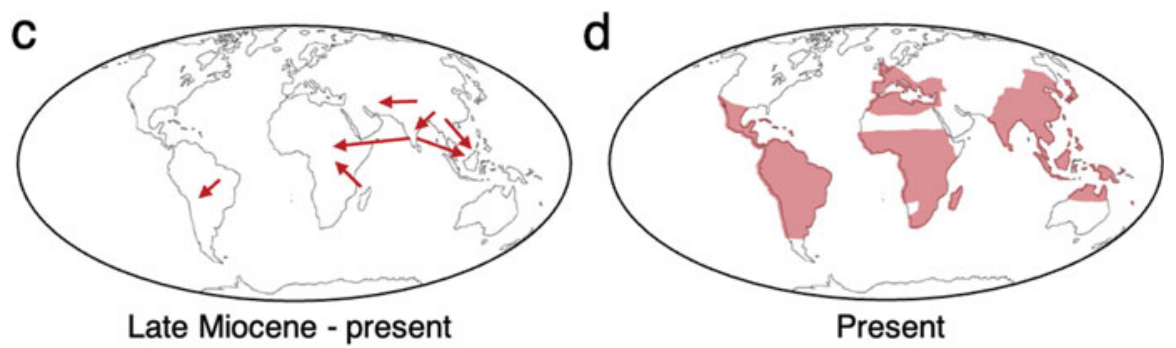

Fig. 1 Biogeographical origin and distribution of Dioscorea species (Viruel et al. 2016). (a) Dioscorea likely originated in the Laurasian Palaearctic in the Late Cretaceous and the Early Eocene (1) and then dispersed from Asia to South America (2). (b) In the Oligocene and Miocene, Dioscorea mainly expanded to the southern region. (c) Some lineages dispersed into new areas in the Miocene and Pliocene, but speciation events decreased in the Quaternary. (d) Geographical distribution in the present era. (Maps are based on C. R. Scotese's PALEOMAP project; www. scotese.com)
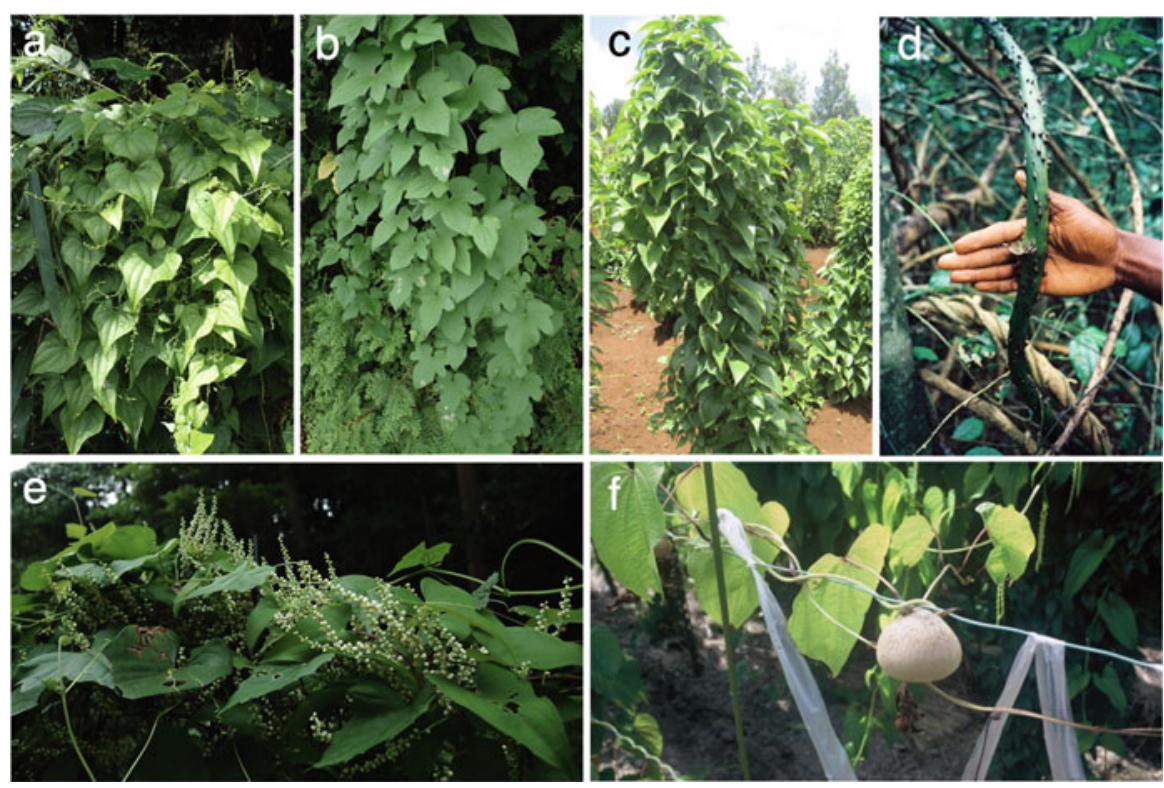

Fig. 2 Morphological diversity of the above-ground parts of Dioscorea species. (a) D. tokoro, (b) D. quinqueloba, (c) D. rotundata, (d) a stem of D. mangenotiana with thorns, (e) flowers of D. japonica, (f) a bulbil of D. bulbifera 


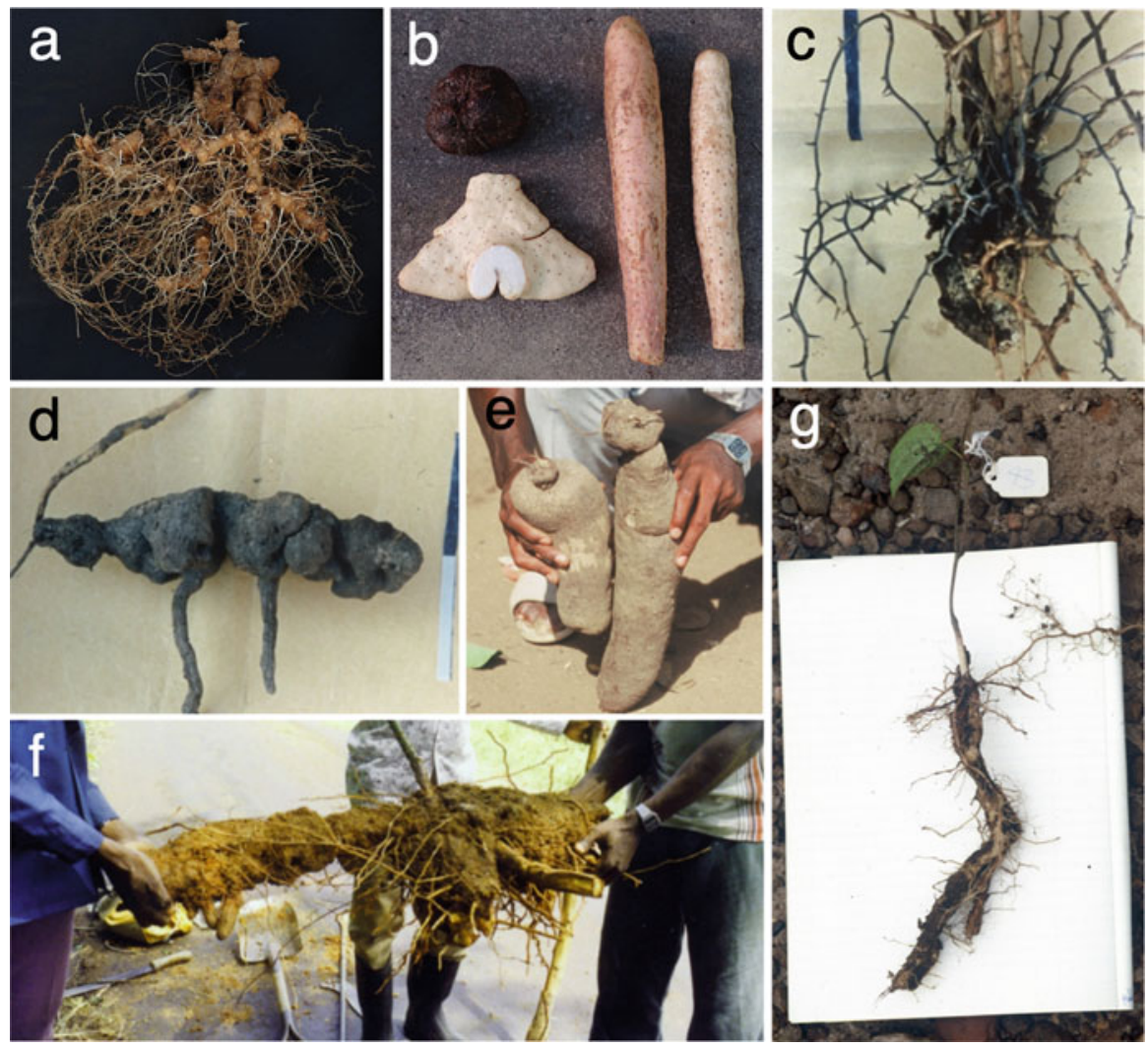

Fig. 3 Rhizomes and tubers of Dioscorea species. (a) rhizomes of D. tokoro, (b) Tukuneimo group (left top), Ichoimo group (left bottom), Nagaimo group (right) in D. polystachya, (c) D. praehensilis, (d) D. minutiflora, (e) D. rotundata (left), D. cayenensis (right), (f) D. mangenotiana, (g) D. abyssinica

Rhizomes and tubers represent morphologically diverse structures that serve as underground starch storage organs (Fig. 3). Because these storage organs serve as food sources for various wild animals, they have evolved defense traits. For example, D. praehensilis has crown roots with spines to protect tubers from burrowing or digging animals (Fig. 3c). Some species of the African clade have thick corky barks covering the pachycaul structure that may provide protection against fire and herbivores (Scott 1897; Maurin et al. 2016). In addition, Dioscorea species produce diverse secondary metabolites such as saponins, alkaloids, and tannins that serve a variety of functions including defense against herbivores (Coursey 1967). Chemical components of some species have medicinal values (Liu et al. 2008; Dutta 2015). 


\section{Ploidy in Dioscorea}

Basic chromosome number of Dioscorea is $x=10$ in the section Stenophora. However, in the section Enantiophyllum that includes the major cultivated species, the basic chromosome number is $x=20$ (Scarcelli et al. 2005; Arnau et al. 2009). Our survey of the available literature shows that at least $33 \%$ of the species in the genus Dioscorea have variable ploidy levels including within the same species (Table 1). As we discuss in the later sections, Dioscorea species have undergone several hybridization events that sometimes led to changes in the ploidy levels. Information on ploidy is important to apply the correct population genomics approaches for the study of Dioscorea. For example, if the sequence reads obtained from a polyploid individual are aligned to a consensus haploid reference genome, variant calling based on the assumption of diploid genome may lead to wrong genotyping results.

Table 1 The various ploidy levels of Dioscorea species

\begin{tabular}{|c|c|c|}
\hline Species $^{\mathrm{a}}$ & $\begin{array}{l}\text { Chromosome } \\
\text { number }\end{array}$ & References \\
\hline D. abyssinica Hochst. & $2 n=40$ & Miège (1954) \\
\hline D. aculeata Webstar & $2 n=40$ & Martin and Ortiz (1963) \\
\hline D. alata $\mathrm{L}$. & $2 \mathrm{n}=40,60,80$ & Arnau et al. (2009) \\
\hline $\begin{array}{l}\text { D. alata var. } \\
\text { purpurea Roxb. }\end{array}$ & $2 n=80$ & Ramachandran (1968) \\
\hline D. althaeoides Knuth & $2 n=20$ & Kiangsu Institute of Botany (1976) \\
\hline $\begin{array}{l}\text { D. asclepiadea Prain \& } \\
\text { Burkill }\end{array}$ & $2 \mathrm{n}=40$ & Takeuchi et al. (1970) \\
\hline D. aspersa Prain \& Burkill & $2 n=40$ & Chin et al. (1985) \\
\hline D. balcanica Košanin & $2 n=20$ & Miège (1954) \\
\hline D. banzhuana Pei \& Ting & $2 n=20$ & Kiangsu Institute of Botany (1976) \\
\hline D. batatas Decne. & $2 \mathrm{n}=140,144$ & Nakajima (1933), Smith (1937) \\
\hline D. belophylla Voigt & $2 \mathrm{n}=50,80,100$ & Raghavan $(1958,1959)$ \\
\hline $\begin{array}{l}\text { D. benthamii Prain \& } \\
\text { Burkill }\end{array}$ & $2 n=$ c. 100 & Chin et al. (1985) \\
\hline $\begin{array}{l}\text { D. bernoulliana } \text { Prain \& } \\
\text { Burkill }\end{array}$ & $2 n=36$ & Martin and Ortiz (1966) \\
\hline D. biformifolia Pei \& Ting & $2 n=20$ & Kiangsu Institute of Botany (1976) \\
\hline D. bulbifera $\mathrm{L}$. & $\begin{array}{l}2 \mathrm{n}=36,40,54 \\
60,80,98-100\end{array}$ & Smith (1937), Miège (1954), Raghavan (1958) \\
\hline D. bulbifera var. bulbifera $\mathrm{L}$. & $2 n=40$ & Paul and Debnath (2019) \\
\hline D. caucasica Lipsky & $2 n=20$ & Meurman (1925) \\
\hline D. cayenensis Lam. & $\begin{array}{l}2 \mathrm{n}=36,54,80 \\
140\end{array}$ & $\begin{array}{l}\text { Smith (1937), Miège (1954), Martin and Ortiz } \\
\text { (1963) }\end{array}$ \\
\hline D. ceratandra Uline & $2 n=36$ & Martin and Ortiz (1963) \\
\hline D. chingii Prain \& Burkill & $2 n=20$ & Kiangsu Institute of Botany (1976) \\
\hline
\end{tabular}


Population Genomics of Yams: Evolution and Domestication of Dioscorea Species

Table 1 (continued)

\begin{tabular}{|c|c|c|}
\hline Species $^{\mathrm{a}}$ & $\begin{array}{l}\text { Chromosome } \\
\text { number }\end{array}$ & References \\
\hline D. cirrhosa Lour. & $2 n=40$ & Chin et al. (1985) \\
\hline $\begin{array}{l}\text { D. cirrhosa var. cylindrica } \\
\text { Ting \& Chang }\end{array}$ & $2 n=40$ & Chin et al. (1985) \\
\hline D. collettii Hook.f. & $2 n=20$ & Kiangsu Institute of Botany (1976) \\
\hline $\begin{array}{l}\text { D. collettii var. hypoglauca } \\
\text { (Palibin) Pei \& Ting }\end{array}$ & $2 n=40$ & Kiangsu Institute of Botany (1976) \\
\hline D. composita Hemsl. & $2 \mathrm{n}=36,54$ & Martin and Ortiz $(1963,1966)$ \\
\hline $\begin{array}{l}\text { D. convolvulacea Schlect. } \\
\text { \& Cham. }\end{array}$ & $2 n=36$ & Martin and Ortiz (1963) \\
\hline D. deltoidea Wall. & $2 \mathrm{n}=20,40$ & Raghavan (1958), Mehra and Sachdeva (1976) \\
\hline D. discolor & $2 n=40$ & Smith (1937) \\
\hline D. dumetorum $\mathrm{Pax}$ & $\begin{array}{l}2 \mathrm{n}=36,40,45 \\
54\end{array}$ & Miège (1954), Baquar (1980) \\
\hline D. escuintlensis Matuda & $2 n=36$ & Martin and Ortiz (1966) \\
\hline D. esculenta Burkill & $\begin{array}{l}2 \mathrm{n}=40,60,80 \\
90,100\end{array}$ & $\begin{array}{l}\text { Miège (1954), Cox et al. (1958), Raghavan } \\
\text { (1958), Chin et al. (1985) }\end{array}$ \\
\hline $\begin{array}{l}\text { D. esculenta } \\
\text { (Cherukizhengu) }\end{array}$ & $2 n=100$ & Ramachandran (1968) \\
\hline $\begin{array}{l}\text { D. esculenta } \\
\text { (Nanakizhengu) }\end{array}$ & $2 n=90$ & Ramachandran (1968) \\
\hline D. exalata Ting \& Chang & $2 \mathrm{n}=60,80$ & Chin et al. (1985) \\
\hline D. fargesii Franch. & $2 n=64$ & Smith (1937) \\
\hline D. floribunda Mart. \& Gal. & $\begin{array}{l}2 \mathrm{n}=36,54,72 \\
144\end{array}$ & Martin and Ortiz $(1963,1966)$ \\
\hline D. fordii Prain \& Burkill & $2 n=40$ & Chin et al. (1985) \\
\hline D. friedrichsthalii R.Knuth & $2 n=36$ & Martin and Ortiz (1963) \\
\hline D. futschuensis Uline & $2 n=40$ & Kiangsu Institute of Botany (1976) \\
\hline D. glabra Roxb. & $2 n=40$ & Mehra and Sachdeva (1976) \\
\hline D. gracillima Miq. & $2 \mathrm{n}=20,40$ & Nakajima (1933), Takeuchi et al. (1970) \\
\hline D. hamiltonii & $2 n=40$ & Paul and Debnath (2019) \\
\hline D. hastata J. Miège & $2 n>120$ & Miège (1954) \\
\hline $\begin{array}{l}\text { D. hemsleyi Prain \& } \\
\text { Burkill }\end{array}$ & $2 n=60$ & Pei et al. (1979) \\
\hline $\begin{array}{l}\text { D. henryi (Prain \& Burkill) } \\
\text { Ting }\end{array}$ & $2 n=40$ & Chin et al. (1985) \\
\hline D. hirtiflora Benth. & $2 n=40$ & Miège (1954) \\
\hline D. hispida Dennst. & $2 n=40$ & Raghavan (1958) \\
\hline D. hondurensis $\mathrm{R}$. Knuth & $2 n=36$ & Martin and Ortiz (1966) \\
\hline D. izuensis Akahori & $2 n=20$ & Takeuchi et al. (1970) \\
\hline D. japonica Thunb. & $2 \mathrm{n}=40,80,100$ & $\begin{array}{l}\text { Nakajima (1933), Araki et al. (1983), Chin } \\
\text { et al. (1985) }\end{array}$ \\
\hline D. kamoonensis Kunth & $2 \mathrm{n}=40,60$ & Chin et al. (1985) \\
\hline D. macroura Harms. & $2 n=40$ & Smith (1937) \\
\hline
\end{tabular}


Table 1 (continued)

\begin{tabular}{|c|c|c|}
\hline Species $^{\mathrm{a}}$ & $\begin{array}{l}\text { Chromosome } \\
\text { number }\end{array}$ & References \\
\hline D. mangenotiana J. Miège & $2 \mathrm{n}=72,80$ & Miège (1954) \\
\hline $\begin{array}{l}\text { D. melanophyma Prain \& } \\
\text { Burkill }\end{array}$ & $2 n=40$ & Chin et al. (1985) \\
\hline D. mexicana Guillemin & $2 n=36$ & Martin and Ortiz (1966) \\
\hline D. minutiflora Engl. & $2 n>120$ & Miège (1954) \\
\hline D. nentaphylla L. & $2 n=120$ & Chin et al. (1985) \\
\hline D. nipponica Makino & $2 \mathrm{n}=20,40$ & $\begin{array}{l}\text { Takeuchi et al. (1970), Kiangsu Institute of } \\
\text { Botany (1976) }\end{array}$ \\
\hline $\begin{array}{l}\text { D. nipponica var. } \\
\text { rosthornii Prain \& Burkill }\end{array}$ & $2 n=40$ & Kiangsu Institute of Botany (1976) \\
\hline D. nitens Prain \& Burkill & $2 n=60$ & Chin et al. (1985) \\
\hline D. nummularia Lam. & $2 \mathrm{n}=60,100,120$ & Lebot et al. (2017) \\
\hline D. opposita Thunb. & $2 n=140$ & Araki et al. (1983) \\
\hline D. oppositifolia L. & $\begin{array}{l}2 \mathrm{n}=40 \\
140,138-142\end{array}$ & $\begin{array}{l}\text { Smith (1937), Raghavan (1958), Chin et al. } \\
(1985)\end{array}$ \\
\hline $\begin{array}{l}\text { D. oppositifolia var linnaei } \\
\text { Prain \& Burkill }\end{array}$ & $2 n=40$ & Ramachandran (1968) \\
\hline D. paniculata Michx & $2 n=36$ & Martin and Ortiz (1966) \\
\hline $\begin{array}{l}\text { D. panthaica } \text { Prain \& } \\
\text { Burkill }\end{array}$ & $2 n=40$ & Kiangsu Institute of Botany (1976) \\
\hline D. parviflora $\mathrm{C}$. T. Ting & $2 n=20$ & Pei et al. (1979) \\
\hline D. pentaphylla $\mathrm{L}$. & $\begin{array}{l}2 \mathrm{n}=40,50,60 \\
80,120,144\end{array}$ & $\begin{array}{l}\text { Smith (1937), Raghavan (1958, 1959), Chin } \\
\text { et al. (1985), Paul and Debnath (2019) }\end{array}$ \\
\hline $\begin{array}{l}\text { D. pentaphylla var. } \\
\text { jacquemontii Prain \& } \\
\text { Burkill }\end{array}$ & $2 \mathrm{n}=40,80$ & Raghavan (1958) \\
\hline $\begin{array}{l}\text { D. pentaphylla } \text { var. linnaei } \\
\text { Prain \& Burkill }\end{array}$ & $2 \mathrm{n}=40,80$ & Raghavan (1958) \\
\hline $\begin{array}{l}\text { D. pentaphylla var. rheedei } \\
\text { Prain \& Burkill }\end{array}$ & $2 n=40$ & Ramachandran (1968) \\
\hline $\begin{array}{l}\text { D. persimilis } \text { Prain \& } \\
\text { Burkill }\end{array}$ & $2 n=40$ & Chin et al. (1985) \\
\hline D. poilanei Prain \& Burkill & $2 n=20$ & Kiangsu Institute of Botany (1976) \\
\hline $\begin{array}{l}\text { D. polygonoides Humb. \& } \\
\text { Bonpl. }\end{array}$ & $2 \mathrm{n}=36,54$ & Martin and Ortiz $(1963,1966)$ \\
\hline $\begin{array}{l}\text { D. polystachya Turcz. } \\
\text { (Ichoimo group) }\end{array}$ & $2 n=100$ & Babil et al. (2013) \\
\hline $\begin{array}{l}\text { D. polystachya Turcz. } \\
\text { (Nagaimo group) }\end{array}$ & $2 \mathrm{n}=140$ & Babil et al. (2013) \\
\hline $\begin{array}{l}\text { D. polystachya Turcz. } \\
\text { (Tsukuneimo group) }\end{array}$ & $2 \mathrm{n}=100$ & Babil et al. (2013) \\
\hline D. praehensilis Benth. & $2 n=40$ & Miège (1954) \\
\hline D. preussii Pax & $2 n=40$ & Miège (1954) \\
\hline D. pubera Blume & $2 n=40$ & Raghavan (1958) \\
\hline D. pyrenaica Bord. & $2 n=24$ & Miège (1954) \\
\hline
\end{tabular}


Population Genomics of Yams: Evolution and Domestication of Dioscorea Species

Table 1 (continued)

\begin{tabular}{|c|c|c|}
\hline Species $^{\mathrm{a}}$ & $\begin{array}{l}\text { Chromosome } \\
\text { number }\end{array}$ & References \\
\hline D. quaternata Gmel. & $2 \mathrm{n}=36,54$ & Jensen (1937), Martin and Ortiz (1966) \\
\hline D. quinqueloba Thunb. & $2 n=20$ & Smith (1937) \\
\hline D. reticulata C. Gay & $2 n=61$ & Smith (1937) \\
\hline D. rotundata Poir. & $2 \mathrm{n}=40,60$ & Martin and Ortiz (1963), Baquar (1980) \\
\hline D. sansibarensis Pax. & $2 n=40$ & Miège (1954) \\
\hline D. sativa $\mathrm{L}$. & $2 n=40$ & Sharma and De (1956) \\
\hline D. sativa Thunb. & $2 n=80$ & Ramachandran (1962) \\
\hline D. septemloba Thunb. & $2 \mathrm{n}=20,40$ & $\begin{array}{l}\text { Takeuchi et al. (1970), Kiangsu Institute of } \\
\text { Botany (1976) }\end{array}$ \\
\hline $\begin{array}{l}\text { D. septemloba var. } \\
\text { sititoana }\end{array}$ & $2 n=40$ & Takeuchi et al. (1970) \\
\hline $\begin{array}{l}\text { D. shimperana Hochst ex } \\
\text { Kunth }\end{array}$ & $2 n=80$ & Baquar (1980) \\
\hline $\begin{array}{l}\text { D. simulans } \text { Prain \& } \\
\text { Burkill }\end{array}$ & $2 n=20$ & Kiangsu Institute of Botany (1976) \\
\hline D. sinuata Vell. & $\begin{array}{l}2 \mathrm{n}=24, \\
34 \text { (male), } \\
36 \text { (female) }\end{array}$ & Meurman (1925), Suessenguth (1921) \\
\hline D. smilacifolia de Wild. & $2 n>120$ & Miège (1954) \\
\hline D. spiculiflora & $2 n=36$ & Martin and Ortiz (1963) \\
\hline D. spinosa Roxb. & $2 n=90$ & Ramachandran (1962) \\
\hline $\begin{array}{l}\text { D. subcalva Prain \& } \\
\text { Burkill }\end{array}$ & $2 n=60$ & Pei et al. (1979) \\
\hline $\begin{array}{l}\text { D. subcalva var. submollis } \\
\text { (Knuth) Ling \& Ting }\end{array}$ & $2 n=60$ & Chin et al. (1985) \\
\hline $\begin{array}{l}\text { D. tentaculigera Prain \& } \\
\text { Burkill }\end{array}$ & $2 n=40$ & Pei et al. (1979) \\
\hline $\begin{array}{l}\text { D. tenuipes Franch. \& } \\
\text { Savat. }\end{array}$ & $2 \mathrm{n}=20,30,40$ & Takeuchi et al. (1970) \\
\hline D. tokoro Makino & $2 n=20$ & Nakajima (1933) \\
\hline D. tomentosa Koenig & $2 \mathrm{n}=40,60$ & Raghavan (1959) \\
\hline D. trifida & $2 \mathrm{n}=40,60^{\mathrm{b}}, 80$ & Bousalem et al. $(2006,2010)$ \\
\hline D. villosa $\mathrm{L}$. & $2 n=60$ & Smith (1937) \\
\hline D. wallichii Hook.f. & $2 n=40$ & Raghavan (1959) \\
\hline $\begin{array}{l}\text { D. yunnanensis Prain \& } \\
\text { Burkill }\end{array}$ & $2 n=40$ & Chin et al. (1985) \\
\hline D. zingiberensis Wright & $2 \mathrm{n}=20,30,40$ & $\begin{array}{l}\text { Kiangsu Institute of Botany (1976), Xiaoqin } \\
\text { et al. (2003) }\end{array}$ \\
\hline Tamus communis $\mathrm{L}^{\mathrm{c}}$ & $2 n=48$ & Meurman (1925) \\
\hline Tamus edulis Lowe ${ }^{\mathrm{c}}$ & $2 n=96$ & Borgen (1974) \\
\hline
\end{tabular}

${ }^{a}$ Species name used in the references

b2C DNA content suggests the existence of the triploid D. trifida (Bousalem et al. 2010)

${ }^{\mathrm{c}}$ Synonym of $D$. communis (L.) Caddick \& Wilkin 


\section{Reference Genome Sequences for Dioscorea}

A reliable reference genome sequence is indispensable for genome diversity studies of a species. The first chromosome-level reference genome obtained for Dioscorea species was that of $D$. rotundata (Tamiru et al. 2017). The size of $D$. rotundata genome was estimated to be $\sim 570$-Mbp using flow cytometry and $k$-mer analyses of genome sequences. The genome contained 26,198 protein coding genes. White Guinea yam genome sequence is distant from those of other monocotyledon species including Poales (Oryza and Brachypodium), Arecales (Elaeis and Phoenix), and Zingiberales (Musa), indicating that Dioscorea lineage was split from other monocotyledons early in the evolution. Publication of the reference genome, which also reported a DNA marker for sex identification in D. rotundata, has served as a catalyst for further studies into genomes of not only D. rotundata (Scarcelli et al. 2019; Bhattacharjee et al. 2020; Zhang et al. 2020; Sugihara et al. 2020) but also of D. alata (Cormier et al. 2019a, b; Sharif et al. 2020) and the pathogens associated with yams such as yam mosaic virus (Silva et al. 2019). D. rotundata scaffolds were generated by combining two types of Illumina short reads: paired-end and mate-pair jump reads. The mate-pair jump reads bridged the contigs assembled using pairedend short reads, with the gaps between the contigs represented with " $N$ " for missing bases. The scaffolds were then ordered to generate a chromosome-level reference genome guided by a linkage map generated by the DNA markers of restriction site associated DNA (RAD)-tags (Baird et al. 2008) using the pseudo-testcross mapping method (Grattapaglia and Sederoff 1994). This reference genome has been shared with the wider scientific community via Ensembl (Howe et al. 2019; ftp://ftp. ensemblgenomes.org/pub/plants/release-48/fasta/dioscorea_rotundata).

Recently, the reference genome of $D$. rotundata has been updated with long reads generated by Oxford Nanopore Technologies (Sugihara et al. 2020). Long readbased de novo genome assembly resulted in longer contigs with a minimum number of missing bases, unlike those constructed by mate-pair jump reads. The newly generated contigs were also ordered using a linkage map generated by massive number of single nucleotide polymorphism (SNP) markers, instead of RAD-markers, obtained from whole-genome re-sequencing of $156 F_{1}$ progeny. This reference genome has been made available via Ensembl (Howe et al. 2019) as D. rotundata reference genome ver. 2 (https://plants.ensembl.org/Dioscorea_rotundata/Info/Index).

Reference genomes of two other Dioscorea species are also available in the public database. The recent chromosome-level reference genome of $D$. alata is yet to be published, but it is accessible on YamBase (https://yambase.org/). Additionally, the reference genome of $D$. dumetorum, which was generated by sequencing with Oxford Nanopore Technologies, has been reported (Siadjeu et al. 2020; https:// pub.uni-bielefeld.de/record/2941469). Both D. rotundata and D. alata belong to the botanical section Enantiophyllum. The D. dumetorum reference genome represents the first genome sequenced from the section Lasiophyton. These multiple reference genomes will facilitate the comparative genomics and pangenome of Dioscorea species and be especially useful for the analysis of the transition of the sex-determination locus within Dioscorea (Cormier et al. 2019a; see Sect. 6). 


\section{Origin and Domestication of Dioscorea Species}

Yams of different Dioscorea species are believed to be independently domesticated in different continents: D. rotundata and D. cayenensis in West and Central Africa, D. alata in Southeast Asia, and D. trifida in South America. However, our knowledge of their origins has been limited until recently. This is mainly due to the frequent hybridization and polyploidization of many species including D. rotundata (Terauchi et al. 1992; Scarcelli et al. 2006; Chaïr et al. 2010; Girma et al. 2014; Scarcelli et al. 2017; Sugihara et al. 2020) and D. alata (Chaïr et al. 2016; Sharif et al. 2020). The recent population genomics studies have started unveiling the domestication processes of the major species (Scarcelli et al. 2019; Sugihara et al. 2020; Sharif et al. 2020).

\subsection{Origin and Domestication of Guinea Yam}

White Guinea yam, D. rotundata, is a true cultigen and the wild species D. abysinica and D. praehensilis have been proposed as its two candidate progenitors (Coursey 1976a, b; Terauchi et al. 1992; Scarcelli et al. 2006; Chaïr et al. 2010; Girma et al. 2014; Scarcelli et al. 2017; Magwé-Tindo et al. 2018). $D$. abyssinica and D. praehensilis are distributed in savannah and rainforest areas, respectively, of West and Central Africa. By comparing whole-genome sequences of 80 D. rotundata, 29 D. abyssinica, 26 D. praehensilis from West Africa (Western D. praehensilis), and 18 D. praehensilis from Cameroon (Cameroonian D. praehensilis), Scarcelli and colleagues recently proposed that D. rotundata was domesticated from $D$. praehensilis in the northern part of Benin within the Niger River basin (Scarcelli et al. 2019). This report is a major contribution towards elucidating the origin of Guinea yam. However, after a careful reassessment of the Scarcelli et al. (2019) data and results, we reached at a different conclusion (Sugihara et al. 2020).

Our study included genome sequences of $336 \mathrm{D}$. rotundata accessions in addition to the $D$. rotundata and wild species accessions analyzed by Scarcelli et al. (2019). First, we conducted clustering analysis and flow cytometry analysis of our 336 D. rotundata accessions. Based on these results, we classified 308 accessions as diploid and 28 accessions as triploid. Focusing on the diploid D. rotundata accessions, we attempted to elucidate their phylogenetic relationships with the wild relative species; D. abyssinica, Western D. praehensilis, and Cameroonian D. praehensilis as reported by Scarcelli et al. (2019). We reconstructed a rooted neighbor-joining tree of four African yam taxa using D. alata, an Asian species, as an outgroup (Fig. 4a). In our result, D. rotundata was genetically closer to D. abyssinica than to D. praehensilis, which was not consistent to Scarcelli's hypothesis indicating that $D$. rotundata was directly domesticated from $D$. praehensilis. To test whether $D$. rotundata was derived from $D$. abyssinica or 
a

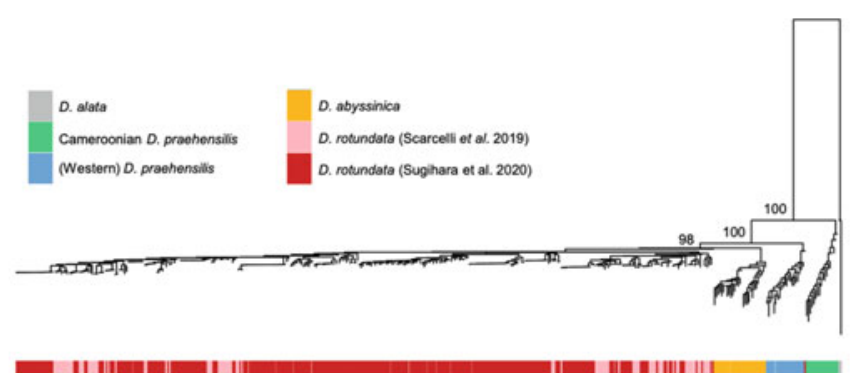

b

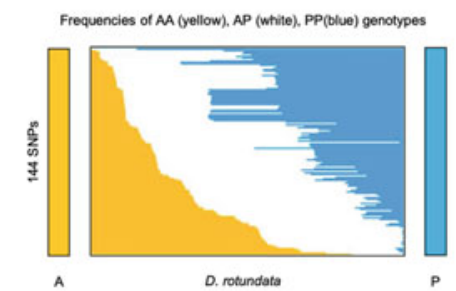

d

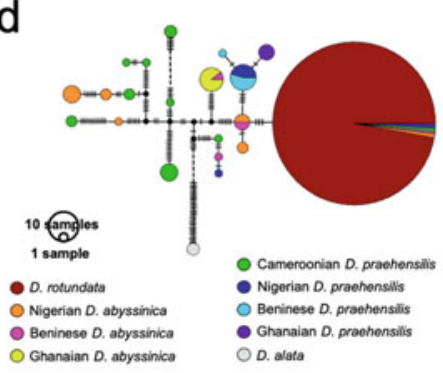

C

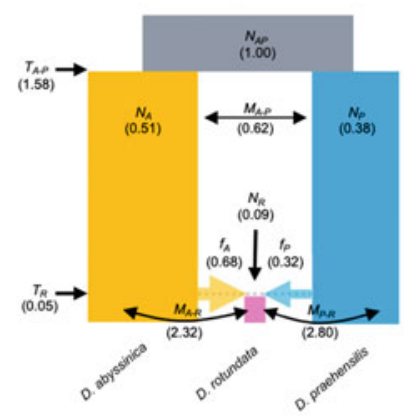

e

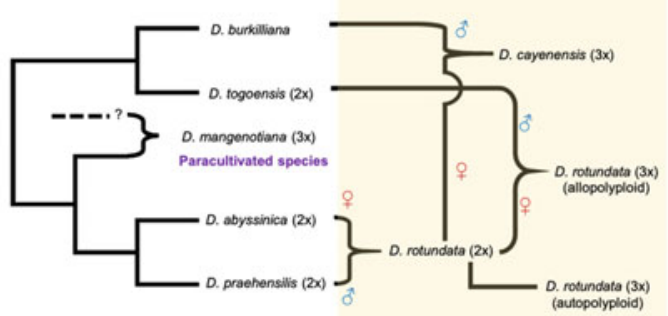

Fig. 4 Domestication history of Guinea yam. (a) Neighbor-joining tree of four African yam taxa reconstructed using D. alata as an outgroup (adopted from Sugihara et al. 2020, Fig. 1c). (b) Frequencies of individuals homozygous for $D$. abyssinica allele (A: indicated by yellow color), homozygous for D. praehensilis allele (P: indicated by blue color), and heterozygous for A and $\mathrm{P}$ (indicated by white color) among the $388 \mathrm{D}$. rotundata sequences as studied for 144 SNPs (adopted from Sugihara et al. 2020, Fig. 2b). (c) Demographic history of D. rotundata as inferred by $\partial \mathrm{a} \partial \mathrm{i}$ (Gutenkunst et al. 2009). N, T, $M$, and $f$ represent a relative population size from the ancestral population $\left(N_{A P}\right)$, divergence time, migration rate, a fraction of genomic contribution, respectively. The $\partial \mathrm{a} \partial \mathrm{i}$ analysis inferred the hybrid origin of $D$. rotundata with the high migration rates between D. rotundata and the two wild relatives (adopted from Sugihara et al. 2020, Fig. 2c). (d) Haplotype network of the whole plastid genomes of 416 D. rotundata (including the triploid accessions), 68 accessions of wild relative species, and two $D$. alata accessions used as the outgroup. The number of vertical dashes represents the number of mutations (adopted from Sugihara et al. 2020, Fig. 3a). (e) Reticulated evolutionary history of Guinea yam (Sugihara et al. 2020; Girma et al. 2014). D. rotundata (white Guinea yam) is derived from a homoploid hybridization between D. abyssinica and D. praehensilis. D. cayenensis (yellow Guinea yam) and the majority of triploid $D$. rotundata are derived from the polyploid hybridization between a female diploid $D$. rotundata and a male African wild yam. At least four species contributed to the gene pool of Guinea yam 
D. praehensilis, we focused on the allele frequencies on 144 SNPs which were oppositely fixed in $D$. abyssinica and D. praehensilis (Fig. 4b). If D. rotundata was derived from either of $D$. abyssinica or $D$. praehensilis, allele frequencies of the analyzed SNPs should be highly skewed to either of the candidate progenitors. However, the allele frequencies of D. rotundata were intermediate. This observation suggested a hybrid origin of $D$. rotundata between $D$. abyssinica and $D$. praehensilis. To conform this hypothesis, we compared the three evolutionary models by $\partial \mathrm{a} \partial \mathrm{i}$ which assesses evolutionary models with their likelihood based on the site frequency spectrum (Gutenkunst et al. 2009). The first model was that $D$. rotundata had been derived from $D$. abyssinica. The second model was that D. rotundata had been derived from D. praehensilis (Scarcelli's hypothesis). The third model was that $D$. rotundata had been hybrid-derived between $D$. abyssinica and $D$. praehensilis. As a result, $\partial \mathrm{a} \partial \mathrm{i}$ showed the highest likelihood in the third model (the hybrid origin of $D$. rotundata) out of the three models.

Our finding suggested that $D$. rotundata is most likely a homoploid hybrid between D. abyssinica and D. praehensilis (Fig. 4b, c; Sugihara et al. 2020). Homoploid hybrid speciation is the formation of a new hybrid species without altering the ploidy levels of the parents (Mallet 2007). The origin of D. rotundata by hybridization seems to be recent when compared with timing of the speciation of D. praehensilis from D. abyssinica (Fig. 4c, d). Genomic contributions from $D$. abyssinica and $D$. praehensilis during the hybridization event were estimated to be $\sim 68 \%$ and $32 \%$, respectively (Fig. 4c). The relative population size of D. rotundata is much smaller than those of its wild relatives, which indicates that D. rotundata was affected by domestication bottleneck. Chloroplast DNA is predominantly inherited maternally in angiosperms. We extracted chloroplast DNA sequences from the whole-genome sequence reads and studied its polymorphisms in our samples. A chloroplast DNA haplotype network suggested that $D$. abyssinica and $D$. praehensilis were the maternal and paternal parents of D. rotundata, respectively (Fig. 4d, e; Sugihara et al. 2020). The hybrid origin of white Guinea yam was initially proposed by Coursey in 1976 based on morphological comparisons (Coursey 1976a). Our results from genome analyses support his hypothesis that spontaneous hybridization between wild yams could have occurred at the artifactual "dump heaps" created by people living in the savannah between the forest and the Sahara (Coursey 1976b).

The most common cases of origin of crops by hybridization accompanies polyploidization (also known as allopolyploidization) as exemplified by bread wheat (Triticum aestivum) (Peng et al. 2011), banana (Musa acuminata) (HeslopHarrison and Schwarzacher 2007), cotton (Gossypium spp.) (Zhang et al. 2015), and canola (Brassica napus) (Chalhoub et al. 2014). The homoploid hybrid speciation in D. rotundata is unique in that its domestication did not involve polyploidization.

We hypothesize that Guinea yam has been established by the process of "ennoblement" (Dumont and Vernier 2000; Mignouna and Dansi 2003; Scarcelli et al. 2006; Chaïr et al. 2010). "Ennoblement" is a traditional farmers" practice that involves collecting tubers of wild yams from the bush and forest and planting them in their fields, and it likely contributes to the genetic diversity of yam through hybridization and introgression (Jarvis and Hodgkin 1999; Scarcelli et al. 2006; 


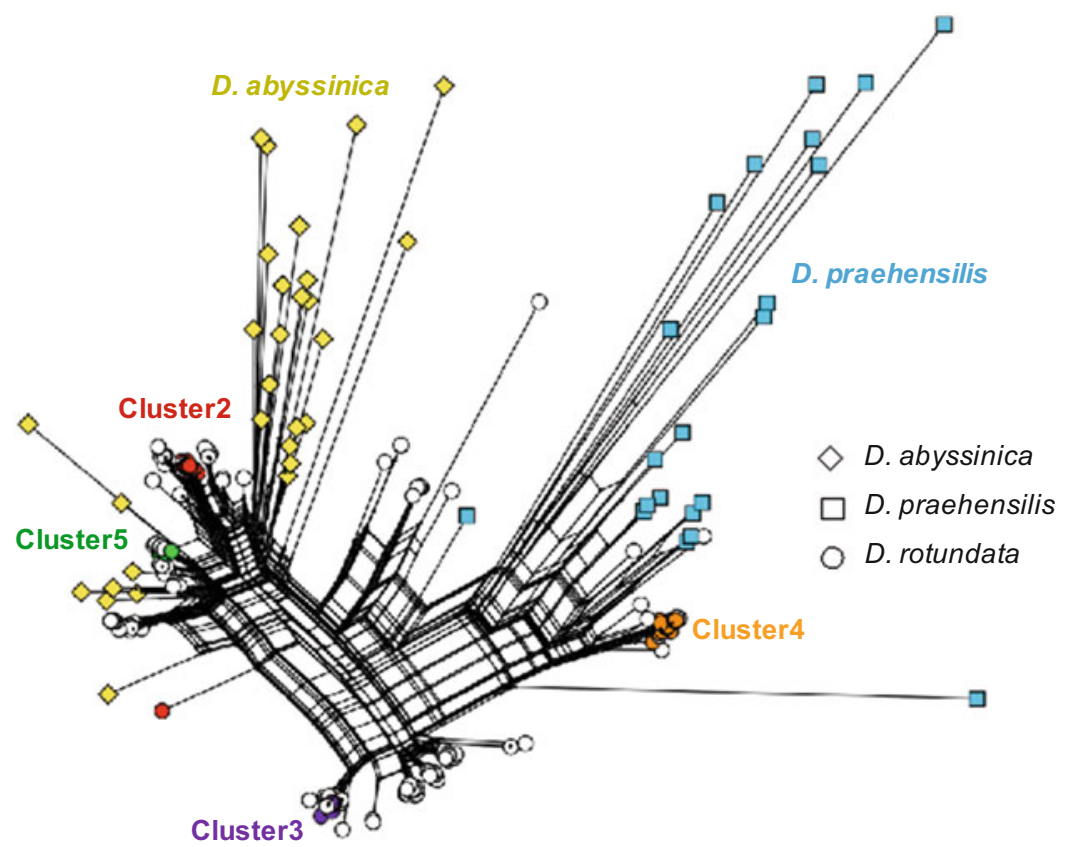

Fig. 5 Genetic relationship among D. rotundata and its wild progenitors around the SWEETIE gene. A Neighbor-Net (adopted from Sugihara et al. 2020, Fig. 4c) was constructed by SplitsTree (Huson and Bryant 2006). Based on STRUCTURE analysis, five clusters (cluster 1-5) were defined in Sugihara et al. (2020). In this analysis, the accessions in cluster 1 were removed because they were triploid. Based on this result, the gene of cluster 2 and 5 were genetically close to D. abyssinica, while that of cluster 4 was genetically close to $D$. praehensilis. This different genetic relationship in the different clusters indicate the introgressions from both wild progenitors

Chaïr et al. 2010). Similar farmers' practices of sympatrically planting crop wild relatives and cultivars often occur in the centers of origin of domesticated plants (Jarvis and Hodgkin 1999).

The locus of the SWEETIE gene is an example that the crop wild relatives contributed to the genetic diversity of $D$. rotundata. The SWEETIE gene is known to be involved in sugar flux (Veyres et al. 2008a, b). In the diploid D. rotundata, this locus showed the signature of extensive introgressions from $D$. abyssinica and $D$. praehensilis (Fig. 5). We identified the introgressions by applying $f_{4}$ statistic (Reich et al. 2009) of population genomics to our diploid D. rotundata accessions and its wild progenitors as analyzed in Scarcelli et al. (2019). The $f_{4}$ statistic can detect genomic regions showing discordant topologies among different genetic groups of $D$. rotundata with respect to $D$. abyssinica and $D$. praehensilis. We hypothesize that this locus was under selection.

In addition to the majority of diploid accessions, triploid accessions of D. rotundata have been identified by flow cytometry analysis (Girma et al. 2014; Sugihara et al. 2020). These triploid $D$. rotundata accessions seem to have been 
derived from a hybridization between the diploid $D$. rotundata and the wild yam species D. togoensis (Fig. 4e; Girma et al. 2014). Since the chloroplast sequences of the triploid $D$. rotundata were shared with the diploid $D$. rotundata, their maternal and paternal parents are likely the diploid $D$. rotundata and $D$. togoensis, respectively (Fig. 4d; Sugihara et al. 2020). Successful interspecific crosses between $D$. rotundata and D. togoensis were also reported (Girma et al. 2014). The triploid $D$. rotundata formed by autopolyploidization seems to be the minority as compared to those formed by allopolyploidization (Girma et al. 2014). It is not easy to distinguish the triploid $D$. rotundata accessions from the diploid accessions based on morphology. However, some morphological traits, such as the presence of barky patches, absence of waxiness, and dark green leaf color, have been shown to correlate with ploidy level (Girma et al. 2014). Agricultural importance of the triploid $D$. rotundata is yet to be studied.

D. cayenensis (yellow Guinea yam) is another species that is likely a triploid hybrid between the diploid $D$. rotundata and the rainforest-adapted wild species D. burkilliana (Fig. 4e; Terauchi et al. 1992; Girma et al. 2014). Based on chloroplast DNA polymorphisms, it was suggested that diploid D. rotundata is the maternal parent of $D$. cayenensis (Terauchi et al. 1992). Using nuclear ribosomal DNA polymorphisms (Terauchi et al. 1992) and Genotype-by-Sequencing (GBS) analysis (Girma et al. 2014), it was inferred that $D$. burkilliana is the paternal parent. $D$. cayenensis has a woody corm above the fleshy tuber, and this trait is shared with $D$. burkilliana. Interestingly, D. burkilliana is also subjected to "ennoblement" together with D. abyssinica and D. praehensilis (Mignouna and Dansi 2003), which probably contributed to its hybridization with $D$. rotundata.

D. mangenotiana (syn. D. baya) is genetically close to Guinea yam (Girma et al. 2014; Magwé-Tindo et al. 2018). Previously, D. mangenotiana and D. baya were considered different species. However, a recent study proposed D. mangenotiana as the adult form of $D$. baya (Magwé-Tindo et al. 2018). D. mangenotiana is a rainforest-adapted wild species characterized by spiny stems and the production of very big tubers (Figs. 2d and 3f; Dounias 2001). The bases of its fleshy edible tubers are attached to very large woody corms, which probably provide protection from herbivores. In Southern Cameroon, D. mangenotiana has long been subjected to "paracultivation" by the Baka Pygmies (Dounias 2001). "Paracultivation" is the exploitation and maintenance of wild plants in their original/natural environments (Dounias 2001). Intriguingly, D. mangenotiana was reported as a triploid species (Girma et al. 2014) with a large number of heterozygous DNA markers, which probably suggests that it may be an allopolyploid. However, no research has been carried out to date to identify the ancestors of $D$. mangenotiana.

\subsection{Origin and Domestication of D. alata}

D. alata (greater yam) is widely cultivated in pantropical regions (Asia, the Pacific, Africa, and the Caribbean) in contrast to D. rotundata that is restricted to Africa and 
the Caribbean. This worldwide dispersion of $D$. alata occurred mainly through human migrations (Sharif et al. 2020). As discussed above, the domestication process of $D$. rotundata seems mainly driven by hybridization and introgression. By contrast, the domestication of $D$. alata was mainly driven by vegetative propagation and autopolyploidization, which caused erratic or no flowering in this species (Arnau et al. 2010; Sharif et al. 2020). This predominant vegetative propagation in $D$. alata is in line with its very low nucleotide diversity $\left(\pi=0.96 \sim 1.29 \times 10^{-5}\right.$ in Fig. 6: Sharif et al. 2020) as compared with the higher level of nucleotide diversity in D. rotundata $\left(\pi=1.48 \times 10^{-3}\right)$ (Sugihara et al. 2020).

Sharif et al. (2020) used genome sequence analysis of 643 accessions spanning four continents to study the dispersion route of $D$. alata, which confirmed the region around tropical Eastern Asia as the geographical origin of D. alata. This finding supports the previous proposal by Burkill (1960) that D. alata was originated in the tropical Eastern Asia. Additionally, Sharif and colleagues hypothesized that D. alata was domesticated independently in the Mainland Southeast Asia and the Pacific (1) in Fig. 6). Their hypothesis is based on the early divergence between the two regions estimated for D. alata (Sharif et al. 2020) as well as the estimated date of early human settlement of Sahul (at least 50,000 years ago) (Bird et al. 2019). After the divergence between the subgroups of Mainland Southeast Asia and the Pacific, D. alata reached the Indian subcontinent (2) in Fig. 6). According to their demographic inference, there was a continuous migration between the Indian subcontinent

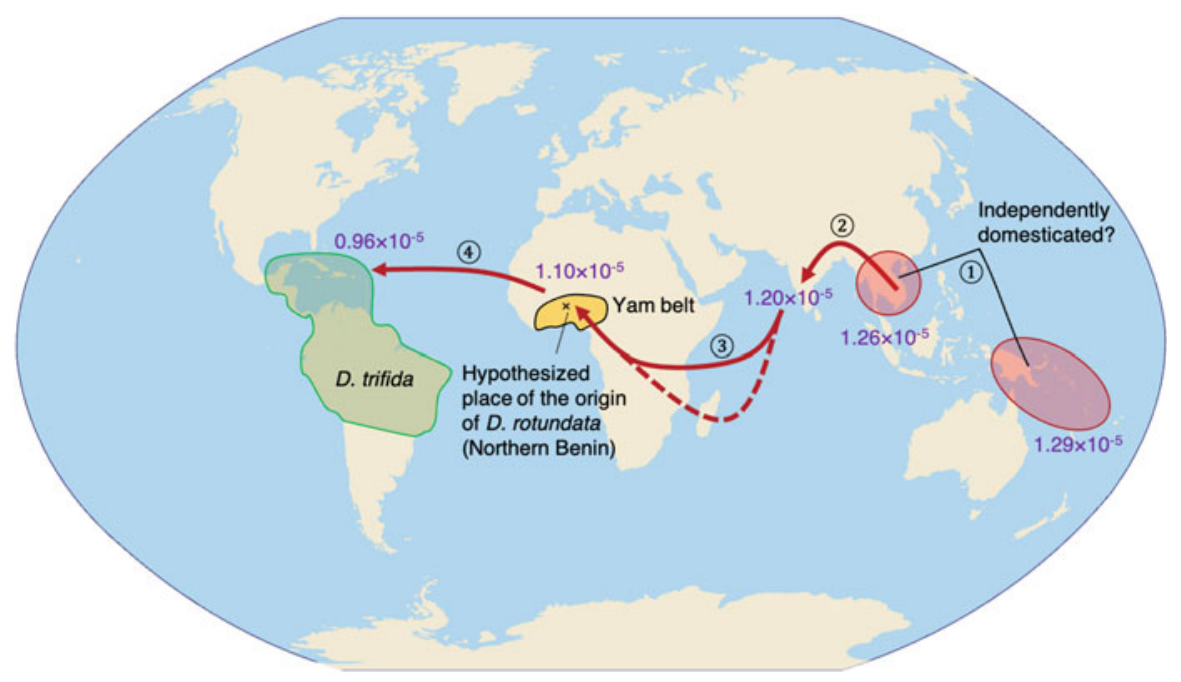

Fig. 6 Global dispersion of D. alata (Sharif et al. 2020) and distributions of other cultivated yam species. Figures in purple color represent nucleotide diversities of the diploid D. alata accessions in different regions. D. alata was originated in Southeast Asia (1)). After its domestication in Southeast Asia, it reached Africa via the Indian Peninsula (2) and (3)), and finally reached the Caribbean (4)) from Africa. The introduction to Africa might be through either Madagascar (broken line in (3)) or East Africa via the Swahili coast (solid line in (3)). The gradual reduction in D. alata nucleotide diversities clearly suggests the founder effects 
and the Pacific. From the Indian subcontinent, D. alata reached Africa (3) in Fig. 6). Since the African and Madagascar $D$. alata are genetically closer to that of the Indian subcontinent than to that from the Mainland Southeast Asia, this dispersion seems to have occurred via the Indian subcontinent (Sharif et al. 2020). The detailed route of how D. alata reached Africa is still unclear. However, it might be through either Madagascar or East Africa via the Swahili coast (3) in Fig. 6). The relatively low nucleotide diversity of African accessions suggests a founder effect from the Indian subcontinent (Sharif et al. 2020). From Africa, D. alata was introduced into the Caribbean (4) in Fig. 6) most probably during the Colombian exchange, which introduced African crops to the tropical America (Boivin et al. 2012). The lowest nucleotide diversity of the Caribbean accessions suggests a strong founder effect from Africa (Sharif et al. 2020; Fig. 6). Taken together, the decreasing nucleotide diversity of $D$. alata clearly reflects the route for its dispersion.

The distribution of the clonal and polyploid accessions of $D$. alata also reflects the route of dispersion of the species (Sharif et al. 2020). Approximately $68 \%$ of the inferred clonal clusters (multi-locus lineages in Sharif et al. 2020) had an intercontinental distribution. The Caribbean accessions had the highest number of the intercontinentally shared clonal clusters, while those of Asia had the lowest. Therefore, the distribution of the clonal clusters reflects dispersion of this species through vegetative propagation. The dispersion route of $D$. alata was also reflected in the distribution of its polyploid accessions. Most of the polyploid accessions are genetically close to either the Asian or the Pacific accessions. This suggests that the polyploidization of $D$. alata occurred several times before migration of the species from Asia and the Pacific to Africa and the Caribbean. Moreover, most triploid accessions were genetically closer to the Asian lineages rather than to the Pacific lineages. This suggests that most triploid accessions were derived from Asia.

The wild progenitor of $D$. alata is still unknown. However, some studies revealed that $D$. alata is phylogenetically close to the wild species $D$. nummularia, D. transverse, and D. hastifolia (Malapa et al. 2005; Chaïr et al. 2016). Especially, D. nummularia, a species native to Melanesia and Island Southeast Asia, is also subjected to a "paracultivation"-like practice (Dounias 2001; Chair et al. 2016). Interestingly, cultivars of natural hybrid between $D$. alata and D. nummularia have been reported and known as "strong yam" by farmers of Vanuatu (Chaïr et al. 2016). These interspecific hybrids were treated as unidentified taxa or erroneously assigned to D. transverse (Malapa et al. 2005; Chaïr et al. 2016). This mis-assignment is probably related to their potential hybrid status (Chair et al. 2016). Recently, researchers have started paying attention to the diversity of $D$. nummularia (Lebot et al. 2017) and attempts are made to introduce the resistance trait of $D$. nummularia against the anthracnose disease caused by Colletotrichum pathogens into $D$. alata by artificial hybridization (Lebot et al. 2019). Although the cross between D. alata and $D$. nummularia resulted in fertile seeds, $D$. nummularia is not regarded as a direct ancestor of $D$. alata (Chaïr et al. 2016). Further population genomics study is needed by including multiple accessions of $D$. nummularia, $D$. transverse, and $D$. hastifolia to clarify the origin of $D$. alata. 


\subsection{Origin and Domestication of D. trifida}

D. trifida of the section Macrogynodium was domesticated in South America and is commonly referred to as the indigenous "Amerindian" yam. Genetic segregation study and cytogenetics suggested that the cultivated $D$. trifida is autotetraploid $(2 \mathrm{n}=4 \times=80)$ (Bousalem et al. 2006), while a wild $D$. trifida with diploid genome $(2 \mathrm{n}=2 \times=40)$ was found in French Guyana (Bousalem et al. 2010). A phylogenetic study based on amplified fragment length polymorphism (AFLP) clearly separated the cultivated $(4 \times)$ and wild $(2 \times)$ D. trifida (Bousalem et al. 2010). A region where the diploid $D$. trifida predominate was also found. $D$. trifida represents a clear case that whole-genome duplication may have played an important role in the domestication of Dioscorea. The autopolyploidization is not a preferred subject in population genomics, but this may help to calibrate the time when the polyploidization happened.

\subsection{Origin and Domestication of D. dumetorum}

D. dumetorum, known as the "trifoliate yam" because of its trifoliate leaves, belongs to the section Lasiophyton. D. dumetorum is widely consumed in West and Central Africa and occurs in both cultivated and wild forms. Despite its high yielding nature and nutritional richness, severe postharvest hardening of the tubers makes D. dumetorum a minor crop (Sefa-Dedeh and Afoakwa 2002). Genetic diversity study of $D$. dumetorum revealed that the accessions from Togo and Nigeria had the highest genetic diversity (Sonibare et al. 2010). This indicates that the center of genetic diversity and the possible origin of $D$. dumetorum might be around Togo and Nigeria. Another study focusing on the accessions from Cameroon identified gene flow and admixture among the accessions, which is probably caused by farmers' breeding practices (Siadjeu et al. 2018). The same study revealed different ploidy levels in $D$. dumetorum and showed that diploids and triploids have different geographical distributions in Cameroon. Interestingly, population genomics study showed that the distribution of the triploid $D$. dumetorum was positively correlated with the region containing a higher level of gene flow (Siadjeu et al. 2018).

\section{Evolution of Sex in Dioscorea Species}

Most Dioscorea species are dioecious, bearing male and female flowers on separate individuals. This sexual system affects genetics and population genomics of the genera and consequently deserves a special attention. Dioecious plants account for 5-6\% of angiosperm species (Renner 2014). Based on its scattered taxonomic distribution, dioecy is suggested to have evolved recently and independently from 
hermaphroditic co-sexual ancestors (Renner and Ricklefs 1995; Charlesworth 2002). Many studies have focused on understanding the process of this large-scale convergent evolution from co-sexual to dioecy in plants. To elucidate the process, sex-determination systems have been studied in several taxa (Akagi et al. 2016, 2019; Harkess et al. 2020).

In Dioscorea, multiple sex-determination systems have been reported by cytological observations and molecular analyses (Table 2). As part of our work on the genetics of $D$. tokoro, a wild species from East Asia, we studied the inheritance and segregation pattern of AFLP markers in an $F_{1}$ family derived from a cross between male and female D. tokoro plants, which suggested an XY/XX (male/ female) sex-determination system in this species (Terauchi and Kahl 1999). Although most Dioscorea species have male heterogametic sex-determination system, female heterogametic sex-determination system (ZZ/ZW) and extra chromosomes in female (XO/XX) have also been reported (Table 2). Sex change of individuals was observed in D. rotundata having female heterogametic sex-determination system (ZZ/ZW) (Tamiru et al. 2017). Here, we review the sex-determination systems of ZZ/ZW and $\mathrm{XY} / \mathrm{XX}$ that occur in $D$. rotundata and $D$. alata, respectively.

Sex in $D$. rotundata is regulated by a female-specific genomic region that we recently identified by QTL-seq analysis of an $F_{1}$ progeny segregating for sex (Tamiru et al. 2017). QTL-seq is an NGS-based bulked segregant analysis (BSA) method to identify the genomic regions underlying traits of interest using progeny derived from crosses made between cultivars/lines showing contrasting phenotypes for the traits (Takagi et al. 2013; Itoh et al. 2019). To identify the genomic region associated with sex in $D$. rotundata, QTL-seq was applied to sequences generated for male and female DNA pools prepared from an $F_{1}$ progeny derived from a cross between male and female plants. Accordingly, a candidate genomic region was detected on chromosome 11 using SNP markers that were heterozygous in the female parent whereas no candidate regions were detected when SNP markers heterozygous in the male parent were used. The candidate genomic region showed significant structural differences between the male and female sequences. PCR amplification and short read mapping analysis further identified a female-specific region within the candidate genomic region delineated by QTL-seq. These results suggest that the sex-determination system of $D$. rotundata is ZZ/ZW (male/female), not XO/XX (male/female).

A DNA maker, "sp16," was developed within the female-specific $(W$-) genomic region of $D$. rotundata for prediction of sex of the plant at the seedling stage (Tamiru et al. 2017). The usefulness of the DNA marker has been demonstrated in diverse D. rotundata accessions (Agre et al. 2020; Denadi et al. 2020). However, the marker type was not perfectly associated with sex, suggesting the manifestation of sex is unstable in D. rotundata over a time period (Tamiru et al. 2017). Sex change is widely known in plants and animals (Policansky 1982). Interestingly, this sex change was rarely observed in the male $D$. rotundata plants, suggesting a gene on the $W$-region with "sp16" marker seems to suppress maleness, and its effect is unstable. 
Table 2 Reported sex-determination systems in Dioscorea

\begin{tabular}{|c|c|c|c|}
\hline Species & $\begin{array}{l}\text { Sex-determination } \\
\text { system }\end{array}$ & Methods & Reference \\
\hline D. alata $\mathrm{L}$. & XY & QTL detection & Cormier et al. (2019a) \\
\hline D. bulbifera $\mathrm{L}$. & XY & $\begin{array}{l}\text { Cytological } \\
\text { observations }\end{array}$ & Ramachandran (1962) \\
\hline D. deltoidea Wall. & ZW & $\begin{array}{l}\text { Cytological } \\
\text { observations }\end{array}$ & $\begin{array}{l}\text { Bhat and Bindroo } \\
(1980)\end{array}$ \\
\hline D. discolor & $\mathrm{a}$ & $\begin{array}{l}\text { Cytological } \\
\text { observations }\end{array}$ & Smith (1937) \\
\hline D. fargesii Franch. & $\mathrm{a}$ & $\begin{array}{l}\text { Cytological } \\
\text { observations }\end{array}$ & Smith (1937) \\
\hline D. gracillima Miq. & XY & $\begin{array}{l}\text { Cytological } \\
\text { observations }\end{array}$ & Nakajima (1937) \\
\hline D. japonica Thunb. & $\mathrm{XY}$ & $\begin{array}{l}\text { Cytological } \\
\text { observations }\end{array}$ & Nakajima (1942) \\
\hline D. macroura Harms. & $\mathrm{a}$ & $\begin{array}{l}\text { Cytological } \\
\text { observations }\end{array}$ & Smith (1937) \\
\hline D. pentaphylla L. & XY & $\begin{array}{l}\text { Cytological } \\
\text { observations }\end{array}$ & Ramachandran (1962) \\
\hline D. reticulata C. Gay & $\mathrm{XO}$ & $\begin{array}{l}\text { Cytological } \\
\text { observations }\end{array}$ & Smith (1937) \\
\hline D. rotundata & ZW & QTL detection & Tamiru et al. (2017) \\
\hline D. sinuata Vell. & $\mathrm{XO}$ & $\begin{array}{l}\text { Cytological } \\
\text { observations }\end{array}$ & Meurman (1925) \\
\hline D. spinosa $\mathrm{Roxb}$. & XY & $\begin{array}{l}\text { Cytological } \\
\text { observations }\end{array}$ & Ramachandran (1962) \\
\hline D. tokoro Makino & XY & AFLP analysis & $\begin{array}{l}\text { Terauchi and Kahl } \\
\text { (1999) }\end{array}$ \\
\hline D. tomentosa Koenig & XY & $\begin{array}{l}\text { Cytological } \\
\text { observations }\end{array}$ & Ramachandran (1962) \\
\hline
\end{tabular}

${ }^{a}$ Heteromorphic chromosomes were reported but no information about sex determination system

In our recent study, we also investigated the genomic contribution of D. abyssinica and D. praehensilis to D. rotundata chromosome-wise (Fig. 7; Sugihara et al. 2020). The chromosome 11 of $D$. rotundata harboring the sex-determination locus was highly skewed towards that of $D$. abyssinica. As described in the previous Sect. 5.1 above, D. rotundata is likely a hybrid species derived from $D$. abyssinica and $D$. praehensilis, and the genetic divergences from both wild progenitors are basically similar across the genome (Sugihara et al. 2020). However, of all the chromosomes, chromosome 11 of $D$. rotundata had the shortest genetic distance from that of $D$. abysinica and the largest genetic distance from that of $D$. praehensilis (Sugihara et al. 2020). Similar interspecies divergence differences between autosomes and sex chromosome have also been reported in the dioecious plant species of the genus Silene (Hu and Filatov 2016). 

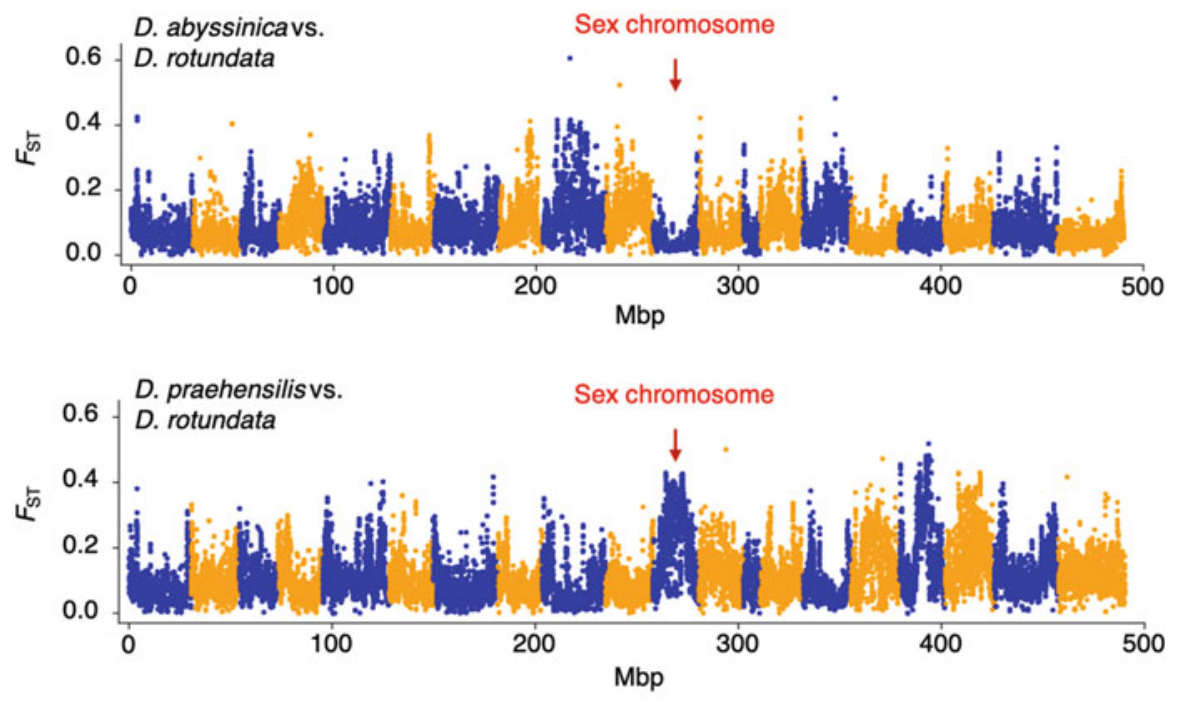

Fig. 7 Genomic scan of $F_{S T}$ values between cultivated yam (D. rotundata) and two wild species D. abyssinica (top) and D. praehensilis (bottom) (adopted from Sugihara et al. 2020, Fig. 2d). Sliding window analysis was conducted with $100-\mathrm{kb}$ window and 20-kb step. Chromosome 11 of $D$. rotundata containing the sex-determining locus shows the shortest distance to that of D. abyssinica and the largest distance to that of $D$. praehensilis

D. alata has a male heterogametic sex-determination system (XY/XX) (Cormier et al. 2019a), which is like the majority of Dioscorea species (Table 2). D. alata belongs to the section Enantiophyllum with $D$. rotundata, a species with a female heterogametic sex-determination system (ZZ/ZW). Interestingly, the genomic region associated with sex of $D$. alata was identified on linkage group 6, which also corresponded to chromosome 6 of D. rotundata (Cormier et al. 2019a). The sex-determination locus of $D$. rotundata was identified on chromosome 11 (Tamiru et al. 2017), suggesting the transition of sex-determination system from XY to ZW occurred in the section Enantiophyllum. A similar transition of sex-determination system was reported in the genus Populus. Most species Populus have the XY sex-determination system, while $P$. alba has the ZW sex-determination system (Müller et al. 2020).

As discussed above, the genus Dioscorea contains many dioecious species with divergent sex-determination systems. Transition of sex-determination systems are presumably involved in species divergence (Kumar et al. 2014). Further genomics research in Dioscorea species will help identify the causative genes involved in sex determination and to clarify how the sex-determination systems have diversified in the genus. Such information will also allow us to manipulate sex of plants for effective cross breeding of yam crops. 


\section{Conclusions and Future Perspectives}

Population genomics and cytogenetics studies have revealed important domestication processes in Dioscorea species, but many questions still remain. For example, we still do not know the key traits and the genes involved in yam domestications, although some studies have identified genes showing signature of selection in D. rotundata including SWEETIE gene in our study (Akakpo et al. 2017; Scarcelli et al. 2019; Sugihara et al. 2020). D. abyssinica and D. praehensilis, the wild relatives of $D$. rotundata, are subjected to an ongoing practice of "ennoblement." Additionally, it has been shown that the most cultivars introduced by "ennoblement" are indeed hybrids between the cultivated and wild yams (Scarcelli et al. 2006). These findings probably indicate that the wild species cannot directly be domesticated to become cultivars and that hybridization was necessary to generate white Guinea yam cultivars. Similar interspecific hybridization was also reported in D. alata (Chaïr et al. 2016). Consequently, analyzing hybridization is important to understand what attributes characterize D. rotundata and other cultivated yams. Probably, D. rotundata was established as a cultivar as a result of heterosis derived from the hybridization between $D$. abyssinica and $D$. praehensilis.

Understanding the genomes of crop wild relatives would facilitate efficient breeding programs. Crop wild relatives are expected to have potentially beneficial alleles that are not available in the cultivars. The farmers unconsciously introduce these beneficial alleles to the cultivars presumably by "ennoblement." Since the genomic regions containing the beneficial alleles should be affected by selective sweeps, population genomics analyses may be able to identify these regions (Akakpo et al. 2017; Scarcelli et al. 2019; Sugihara et al. 2020). Currently, there is no evidence that these candidate selective sweeps affected any phenotypes. However future functional studies of the identified genes would reveal their impact on the change of traits in the crops.

Another standing question is how many times the domestication processes occurred in the various cultivated Dioscorea species. A recent study hypothesized multiple domestication processes of D. alata in separate regions (Sharif et al. 2020). The cultivated yam landraces from Southern Ethiopian are phylogenetically close to the cultivated gene pools of $D$. rotundata, but they were clearly separate from Nigerian D. rotundata (Tamiru et al. 2007). Although the model-based population genetics/genomics is needed to infer the detailed demographic history, this result may suggest independent domestication processes of D. rotundata in Ethiopia (or East Africa) and Nigeria.

In this chapter, the importance of hybridization and polyploidization for the domestication of Dioscorea species has been discussed. Some of these events appear to have played an important role in yam domestication. In recent years, our knowledge of yam domestication has dramatically improved thanks to the advances in sequencing technologies and statistical methods for population genomics analysis. These developments also allowed us to identify, among others, the transition of the sex-determination system in the section Enantiophyllum. Future studies should 
further unravel the complex evolutionary history of Dioscorea species including hybridization, polyploidization, and sexual/asexual propagation.

Acknowledgements This study was supported by AfricaYam Project funded by the Bill and Melinda Gates Foundation (BMGF, grant number OPP1052998). This work is dedicated to the memory of Günter Kahl who has pioneered genetics and molecular biology studies of Dioscorea.

\section{References}

Agre P, Nwachukwu C, Olasanmi B, Obidiegwu J, Nwachukwu E, Adebola P, et al. Sample preservation and plant sex prediction in white Guinea yam (Dioscorea rotundata Poir.). J Appl Biotechnol Rep. 2020;7(3):145-51.

Akagi T, Henry IM, Kawai T, Comai L, Tao R. Epigenetic regulation of the sex determination gene MeGI in polyploid persimmon. Plant Cell. 2016;28(12):2905-15.

Akagi T, Pilkington SM, Varkonyi-Gasic E, Henry IM, Sugano SS, Sonoda M, et al. Two Ychromosome-encoded genes determine sex in kiwifruit. Nat Plants. 2019;5(8):801-9.

Akakpo R, Scarcelli N, Chaïr H, Dansi A, Djedatin G, Thuillet AC, et al. Molecular basis of African yam domestication: analyses of selection point to root development, starch biosynthesis, and photosynthesis related genes. BMC Genomics. 2017;18(1):782.

Araki H, Harada T, Yakuwa T. Some characteristics of interspecific hybrids between Dioscorea japonica Thunb. and Dioscorea opposita Thunb. J Japan Soc Hort Sci. 1983;52(2):153-8.

Arnau G, Nemorin A, Maledon E, Abraham K. Revision of ploidy status of Dioscorea alata L. (Dioscoreaceae) by cytogenetic and microsatellite segregation analysis. Theor Appl Genet. 2009;118(7):1239-49.

Arnau G, Abraham K, Sheela MN, Chaïr H, Sartie A, Asiedu R. Yams. In: Bradshaw J, editor. Root and tuber crops. Handbook of plant breeding, vol. 7. New York: Springer; 2010. p. 127-48.

Babil P, Kondo S, Iwata H, Kushikawa S, Shiwachi H. Intra-specific ploidy variations in cultivated Chinese yam (Dioscorea polystachya Turcz.). Trop Agr Develop. 2013;57(3):101-7.

Baird NA, Etter PD, Atwood TS, Currey MC, Shiver AL, Lewis ZA, et al. Rapid SNP discovery and genetic mapping using sequenced RAD markers. PLoS One. 2008;3(10):e3376.

Baquar SR. Chromosome behaviour in Nigerian yams (Dioscorea). Genetica. 1980;54(1):1-9.

Bhat BK, Bindroo BB. Sex chromosomes in Dioscorea deltoidea Wall. Cytologia. 1980;45 (4):739-42.

Bhattacharjee R, Agre P, Bauchet G, De Koeyer D, Lopez-Montes A, Kumar PL, et al. Genotypingby-sequencing to unlock genetic diversity and population structure in White yam (Dioscorea rotundata Poir.). Agronomy. 2020;10(9):1437.

Bird MI, Condie SA, O'Connor S, O'Grady D, Reepmeyer C, Ulm S, et al. Early human settlement of Sahul was not an accident. Sci Rep. 2019;9:8220.

Boivin N, Fuller DQ, Crowther A. Old World globalization and the Columbian exchange: comparison and contrast. World Archaeol. 2012;44(3):452-69.

Borgen L. Chromosome numbers of Macaronesian flowering plants II. Norw J Bot. 1974;21:195210.

Bousalem M, Arnau G, Hochu I, Arnolin R, Viader V, Santoni S, et al. Microsatellite segregation analysis and cytogenetic evidence for tetrasomic inheritance in the American yam Dioscorea trifida and a new basic chromosome number in the Dioscoreae. Theor Appl Genet. 2006;113 (3):439-51.

Bousalem M, Viader V, Mariac C, Gomez RM, Hochu I, Santoni S, et al. Evidence of diploidy in the wild Amerindian yam, a putative progenitor of the endangered species Dioscorea trifida (Dioscoreaceae). Genome. 2010;53(5):371-83. 
Burkill IH. The organography and the evolution of the Dioscoreaceae, the family of the yams. J Linn Soc. 1960;56:319-412.

Caddick LR, Wilkin P, Rudall PJ, Hedderson TAJ, Chase MW. Yams reclassified: a recircumscription of Dioscoreaceae and Dioscoreales. Taxon. 2002;51(1):103-14.

Chaïr H, Cornet D, Deu M, Baco MN, Agbangla A, Duval MF, et al. Impact of farmer selection on yam genetic diversity. Conserv Genet. 2010;11(6):2255-65.

Chaïr H, Sardos J, Supply A, Mournet P, Malapa R, Lebot V. Plastid phylogenetics of Oceania yams (Dioscorea spp., Dioscoreaceae) reveals natural interspecific hybridization of the greater yam (D. alata). Bot J Linn Soc. 2016;180(3):319-33.

Chalhoub B, Denoeud F, Liu S, Parkin IAP, Tang H, Wang X, et al. Early allopolyploid evolution in the post-Neolithic Brassica napus oilseed genome. Science. 2014;345(6199):950-3.

Charlesworth D. Plant sex determination and sex chromosomes. Heredity. 2002;88(2):94-101.

Chin HC, Chang MC, Ling PP, Ting CT, Dou FP. A cytotaxonomic study on Chinese Dioscorea L. the chromosome numbers and their relation to the origin and evolution of the genus. Acta Phytotax Sin. 1985;23(1):11-8.

Cormier F, Lawac F, Maledon E, Gravillon MC, Nudol E, Mournet P, et al. A reference highdensity genetic map of greater yam (Dioscorea alata L.). Theor Appl Genet. 2019a;132 (6): 1733-44.

Cormier F, Mournet P, Causse S, Arnau G, Maledon E, Gomez RM, et al. Development of a costeffective single nucleotide polymorphism genotyping array for management of greater yam germplasm collections. Ecol Evol. 2019b;9(10):5617-36.

Coursey DG. Yams. An account of the nature, origins, cultivation and utilisation of the useful members of the Dioscoreaceae. In: Rhind D, et al., editors. Tropical agricultural series. London: Longmans; 1967. p. 108-29.

Coursey DG. The civilization of the yam: interrelationships of man and yams in Africa and the Indo-Pacific region. Archaeol Phys Anthropol Ocean. 1972;7(3):215-33.

Coursey DG. Yams, Dioscorea spp. (Dioscoreaceae). In: Simmonds NW, editor. Evolution of crop plants. London: Longman; 1976a. p. 70-4.

Coursey DG. The origins and domestication of yams in Africa. In: Harlan JR, editor. Origins of African plant domestication. Boston: De Gruyter Mouton; 1976b. p. 383-408.

Couto RS, Martins AC, Bolson M, Lopes RC, Smidt EC, Braga JMA. Time calibrated tree of Dioscorea (Dioscoreaceae) indicates four origins of yams in the Neotropics since the Eocene. Bot J Linn Soc. 2018;188(2):144-60.

Cox DK, Corzo AH, Matuda E, Durán JGG. Estudio de las Dioscoreas Mexicanas. I. Dioscorea spiculiflora Hemsl. Bol Soc Bot Mex. 1958;22:12-27.

Denadi N, Gandonou C, Missihoun AA, Zoundjihékpon J, Quinet M. Plant sex prediction using genetic markers in cultivated yams (Dioscorea rotundata Poir.) in Benin. Agronomy. 2020;10 (10): 1521.

Dounias E. The management of wild yam tubers by the Baka pygmies in southern Cameroon. Afr Study Monogr Suppl. 2001;26:135-56.

Dumont R, Vernier P. Domestication of yams (Dioscorea cayenensis-rotundata) within the Bariba ethnic group in Benin. Outlook Agric. 2000;29(2):137-42.

Dutta B. Food and medicinal values of certain species of Dioscorea with special reference to Assam. J Pharmacogn Phytochem. 2015;3(4):15-8.

FAOSTAT (2018) Food and Agriculture Organization. http://www.fao.org/statistics. Accessed 10 May 2020

Girma G, Hyma KE, Asiedu R, Mitchell SE, Gedil M, Spillane C. Next-generation sequencing based genotyping, cytometry and phenotyping for understanding diversity and evolution of guinea yams. Theor Appl Genet. 2014;127(8):1783-94.

Grattapaglia D, Sederoff R. Genetic linkage maps of Eucalyptus grandis and Eucalyptus urophylla using a pseudo-testcross: mapping strategy and RAPD markers. Genetics. 1994;137(4):112137. 
Gutenkunst RN, Hernandez RD, Williamson SH, Bustamante CD. Inferring the joint demographic history of multiple populations from multidimensional SNP frequency data. PLoS Genet. 2009;5(10):e1000695.

Harkess A, Huang K, van der Hulst R, Tissen B, Caplan JL, Koppula A, et al. Sex determination by two Y-linked genes in garden asparagus. Plant Cell. 2020;32(6):1790-6.

Heslop-Harrison JS, Schwarzacher T. Domestication, genomics and the future for banana. Ann Bot. 2007;100(5):1073-84.

Howe KL, Contreras-Moreira B, De Silva N, Maslen G, Akanni W, Allen J, et al. Ensembl genomes 2020 - enabling non-vertebrate genomic research. Nucleic Acids Res. 2019;48(D1):D689-95.

$\mathrm{Hu}$ XS, Filatov DA. The large-X effect in plants: increased species divergence and reduced gene flow on the Silene X-chromosome. Mol Ecol. 2016;25(11):2609-19.

Huber H. Dioscoreaceae. In: Kubitzki K, editor. The families and genera of vascular plants, Flowering plants: monocotyledons, vol. III. Berlin: Springer; 1998. p. 216-35.

Huson DH, Bryant D. Application of phylogenetic networks in evolutionary studies. Mol Biol Evol. 2006;23(2):254-67.

Ikiriza H, Ogwang PE, Peter EL, Hedmon O, Tolo CU, Abubaker M, et al. Dioscorea bulbifera, a highly threatened African medicinal plant, a review. Cogent Biol. 2019;5(1):1631561.

Itoh N, Segawa T, Tamiru M, Abe A, Sakamoto S, Uemura A, et al. Next-generation sequencingbased bulked segregant analysis for QTL mapping in the heterozygous species Brassica rapa. Theor Appl Genet. 2019;132(10):2913-25.

Jarvis DI, Hodgkin T. Wild relatives and crop cultivars: detecting natural introgression and farmer selection of new genetic combinations in agroecosystems. Mol Ecol. 1999;8:S159-73.

Jensen HW. Meiosis in several species of dioecious Monocotyledoneae I. The possibility of sexchromosomes. Cytologia. 1937;1:96-103.

Kiangsu Institute of Botany. Studies on Chinese Dioscorea sect. Stenophora Pr et Burk and their chromosome numbers. Acta Phytotax Sin. 1976;14(1):65-72.

Knuth R. Dioscoreaceae. In: Engler HGA, editor. Das Pflanzenrich, 87 (IV. 43). Leipzig: H. R. Engelmann (J. Cramer); 1924. p. 1-387.

Kumar S, Kumari R, Sharma V. Genetics of dioecy and causal sex chromosomes in plants. J Genet. 2014;93(1):241-77.

Lebot V, Malapa R, Abraham K. The Pacific yam (Dioscorea nummularia Lam.), an underexploited tuber crop from Melanesia. Genet Resour Crop Evol. 2017;64(1):217-35.

Lebot V, Abraham K, Kaoh J, Rogers C, Molisalé T. Development of anthracnose resistant hybrids of the greater yam (Dioscorea alata L.) and interspecific hybrids with D. nummularia Lam. Genet Resour Crop Evol. 2019;66(4):871-83.

Liu XT, Wang ZZ, Xiao W, Zhao HW, Hu J, Yu B. Cholestane and spirostane glycosides from the rhizomes of Dioscorea septemloba. Phytochemistry. 2008;69(6):1411-8.

Magwé-Tindo J, Wieringa JJ, Sonké B, Zapfack L, Vigouroux Y, Couvreur TLP, et al. Guinea yam (Dioscorea spp., Dioscoreaceae) wild relatives identified using whole plastome phylogenetic analyses. Taxon. 2018;67(5):905-15.

Malapa R, Arnau G, Noyer JL, Lebot V. Genetic diversity of the greater yam (Dioscorea alata L.) and relatedness to $D$. nummularia Lam. and $D$. transversa $\mathrm{Br}$. as revealed with AFLP markers. Genet Resour Crop Evol. 2005;52(7):919-29.

Mallet J. Hybrid speciation. Nature. 2007;446(7133):279-83.

Martin FW, Ortiz S. Chromosome numbers and behavior in some species of Dioscorea. Cytologia. 1963;28(1):96-101.

Martin FW, Ortiz S. New chromosome numbers in some Dioscorea species. Cytologia. 1966;31 (1):105-7.

Maurin O, Muasya AM, Catalan P, Shongwe EZ, Viruel J, Wilkin P, et al. Diversification into novel habitats in the Africa clade of Dioscorea (Dioscoreaceae): erect habit and elephant's foot tubers. BMC Evol Biol. 2016;16(1):238.

Mehra PN, Sachdeva SK. Cytological observations on some W. Himalayan Monocots IV. Several families. Cytologia. 1976;41(1):31-53. 
Meurman O. The chromosomal behavior of some dioecious plants and their relatives with special reference to the sex chromosomes. Soc Scient Fenn Comm Biol II. 1925;3:1-105.

Miège $\mathrm{J}$. Nombres chromosomiques et rèpartition gèographique de quelques plantes tropicales et èquatoriales. Rev Cytol Biol Vég Bot. 1954;15(4):312-48.

Mignouna HD, Dansi A. Yam (Dioscorea spp.) domestication by the Nago and Fon ethnic groups in Benin. Genet Resour Crop Evol. 2003;50(5):519-28.

Mignouna HD, Abang MM, Asiedu R. Harnessing modern biotechnology for tropical tuber crop improvement: yam (Dioscorea spp.) molecular breeding. Afr J Biotechnol. 2003;2(12):478-85.

Müller NA, Kersten B, Leite Montalvão AP, Mähler N, Bernhardsson C, Bräutigam K, et al. A single gene underlies the dynamic evolution of poplar sex determination. Nat Plants. 2020;6 (6):630-7.

Murty YS, Purnima. Morphology, anatomy and development of bulbil in some dioscoreas. Proc Indian Acad Sci (Plant Sci). 1983;92(6):443-9.

Nakajima G. Chromosome numbers in some angiosperms. Jap J Genet. 1933;9(1):1-5.

Nakajima G. Cytological studies in some dioecious plants. Cytologia. 1937;1:282-92.

Nakajima G. Cytological studies in some flowering dioecious plants, with special reference to the sex chromosomes. Cytologia. 1942;12(2-3):262-70.

Noda H, Yamashita J, Fuse S, Pooma R, Poopath M, Tobe H, et al. A large-scale phylogenetic analysis of Dioscorea (Dioscoreaceae), with reference to character evolution and subgeneric recognition. Acta Phytotax Geobot. 2020;71(2):103-28.

Obidiegwu JE, Akpabio EM. The geography of yam cultivation in southern Nigeria: exploring its social meanings and cultural functions. J Ethn Foods. 2017;4(1):28-35.

Obidiegwu JE, Lyons JB, Chilaka CA. The Dioscorea genus (Yam) - an appraisal of nutritional and therapeutic potentials. Foods. 2020;9(9):1304.

Paul C, Debnath B. A report on new chromosome number of three Dioscorea species. Plant Sci Today. 2019;6(2):147-50.

Pei C, Ting CT, Chin HC, Su P, Tang SY, Chang HC. A preliminary systematic study of Dioscorea L. sect. Stenophora Uline. Acta Phytotax Sin. 1979;17(3):61-72.

Peng JH, Sun D, Nevo E. Domestication evolution, genetics and genomics in wheat. Mol Breeding. 2011;28(3):281-301.

Policansky D. Sex change in plants and animals. Annu Rev Ecol Syst. 1982;13(1):471-95.

Prain D, Burkill IH. An account of the genus Dioscorea in the east, part 1: the species which twine to the left. Ann Roy Bot Gard. 1936;14:1-210.

Prain D, Burkill IH. An account of the genus Dioscorea in the east, part 2: the species which twine to the right. Ann Roy Bot Gard. 1939;14:211-528.

Raghavan RS. A chromosome survey of indian dioscoreas. Proc Indian Acad Sci B. 1958;48(1):5963.

Raghavan RS. A note on some south Indian species of the genus Dioscorea. Curr Sci. 1959;28 (8):337-8.

Ramachandran K. Studies on the cytology and sex determination of the Dioscoreaceae. J Indian Bot Soc. 1962;41:93-8.

Ramachandran K. Cytological studies in Dioscoreaceae. Cytologia. 1968;33(3-4):401-10.

Ramu P, Esuma W, Kawuki R, Rabbi IY, Egesi C, Bredeson JV, et al. Cassava haplotype map highlights fixation of deleterious mutations during clonal propagation. Nat Genet. 2017;49 (6):959-63.

Reich D, Thangaraj K, Patterson N, Price AL, Singh L. Reconstructing Indian population history. Nature. 2009;461(7263):489-94.

Renner SS. The relative and absolute frequencies of angiosperm sexual systems: dioecy, monoecy, gynodioecy, and an updated online database. Am J Bot. 2014;101(10):1588-96.

Renner SS, Ricklefs RE. Dioecy and its correlates in the flowering plants. Am J Bot. 1995;82 (5):596-606. 
Scarcelli N, Daïnou O, Agbangla C, Tostain S, Pham JL. Segregation patterns of isozyme loci and microsatellite markers show the diploidy of African yam Dioscorea rotundata $(2 \mathrm{n}=40)$. Theor Appl Genet. 2005;111(2):226-32.

Scarcelli N, Tostain S, Vigouroux Y, Agbangla C, Daïnou O, Pham JL. Farmers' use of wild relative and sexual reproduction in a vegetatively propagated crop. The case of yam in Benin. Mol Ecol. 2006;15(9):2421-31.

Scarcelli N, Chaïr H, Causse S, Vesta R, Couvreur TLP, Vigouroux Y. Crop wild relative conservation: wild yams are not that wild. Biol Conserv. 2017;210:325-33.

Scarcelli N, Cubry P, Akakpo R, Thuillet AC, Obidiegwu J, Baco MN, et al. Yam genomics supports West Africa as a major cradle of crop domestication. Sci Adv. 2019;5(5):eaaw1947.

Scott DH. On two new instances of spinous roots. Ann Bot. 1897;11(42):327-32.

Sefa-Dedeh S, Afoakwa EO. Biochemical and textural changes in trifoliate yam Dioscorea dumetorum tubers after harvest. Food Chem. 2002;79(1):27-40.

Sharif BM, Burgarella C, Cormier F, Mournet P, Causse S, Van KN, et al. Genome-wide genotyping elucidates the geographical diversification and dispersal of the polyploid and clonally propagated yam (Dioscorea alata). Ann Bot. 2020;126(6):1029-38.

Sharma AK, De DN. Polyploidy in Dioscorea. Genetica. 1956;28(1):112-20.

Siadjeu C, Mayland-Quellhorst E, Albach DC. Genetic diversity and population structure of trifoliate yam (Dioscorea dumetorum Kunth) in Cameroon revealed by genotyping-by-sequencing (GBS). BMC Plant Biol. 2018;18(1):359.

Siadjeu C, Pucker B, Viehöver P, Albach DC, Weisshaar B. High contiguity de novo genome sequence assembly of trifoliate yam (Dioscorea dumetorum) using long read sequencing. Genes. 2020;11(3):274.

Silva G, Bömer M, Rathnayake AI, Sewe SO, Visendi P, Oyekanmi JO, et al. Molecular characterization of a new virus species identified in yam (Dioscorea spp.) by high-throughput sequencing. Plants. 2019;8(6):167.

Smith BW. Notes on the cytology and distribution of the Dioscoreaceae. Bull Torrey Bot Club. 1937;64(4):189-97.

Sonibare MA, Asiedu R, Albach DC. Genetic diversity of Dioscorea dumetorum (Kunth) Pax using amplified fragment length polymorphisms (AFLP) and cpDNA. Biochem Syst Ecol. 2010;38 (3):320-34.

Suessenguth. Bemerkungen zur meiotischen und somatischen Kernteilung bei einigen Monokotylen. Flora Allg Bot Ztg. 1921;114(3-4):313-28.

Sugihara Y, Darkwa K, Yaegashi H, Natsume S, Shimizu M, Abe A, et al. Genome analyses reveal the hybrid origin of the staple crop white Guinea yam (Dioscorea rotundata). Proc Natl Acad Sci U S A. 2020;117(50):31987-92.

Takagi H, Abe A, Yoshida K, Kosugi S, Natsume S, Mitsuoka C, et al. QTL-seq: rapid mapping of quantitative trait loci in rice by whole genome resequencing of DNA from two bulked populations. Plant J. 2013;74(1):174-83.

Takeuchi Y, Iwao T, Akahori A. Chromosome numbers of some Japanese Dioscorea species. Acta Phytotax Geobot. 1970;24(4-6):168-73.

Tamiru M, Becker HC, Maass BL. Genetic diversity in yam germplasm from Ethiopia and their relatedness to the main cultivated Dioscorea species assessed by AFLP markers. Crop Sci. 2007;47(4):1744-53.

Tamiru M, Natsume S, Takagi H, White B, Yaegashi H, Shimizu M, et al. Genome sequencing of the staple food crop white Guinea yam enables the development of a molecular marker for sex determination. BMC Biol. 2017;15(1):86.

Terauchi R, Kahl G. Sex determination in Dioscorea tokoro, a wild yam species. In: Ainsworth CC, editor. Sex determination in plants. Oxford: Bios Scientific Publishers; 1999. p. 163-71.

Terauchi R, Terachi T, Tsunewaki K. Intraspecific variation of chloroplast DNA in Dioscorea bulbifera L. Theor Appl Genet. 1991;81(4):461-70. 
Terauchi R, Chikaleke VA, Thottappilly G, Hahn SK. Origin and phylogeny of Guinea yams as revealed by RFLP analysis of chloroplast DNA and nuclear ribosomal DNA. Theor Appl Genet. 1992;83(6-7):743-51.

Uline EB. Eine monographie der Dioscoreaceen. Bot Jahrb Syst. 1898;25:126-65.

Veyres N, Danon A, Aono M, Galliot S, Karibasappa YB, Diet A, et al. The Arabidopsis sweetie mutant is affected in carbohydrate metabolism and defective in the control of growth, development and senescence. Plant J. 2008a;55(4):665-86.

Veyres N, Aono M, Sangwan-Norree BS, Sangwan RS. Has Arabidopsis SWEETIE protein a role in sugar flux and utilization? Plant Signal Behav. 2008b;3(9):722-5.

Viruel J, Segarra-Moragues JG, Raz L, Forest F, Wilkin P, Sanmartín I, et al. Late Cretaceous-Early Eocene origin of yams (Dioscorea, Dioscoreaceae) in the Laurasian Palaearctic and their subsequent Oligocene-Miocene diversification. J Biogeogr. 2016;43(4):750-62.

WCSP. World checklist of selected plant families. Kew: Facilitated by the Royal Botanic Gardens; 2020. http://wcsp.science.kew.org/. Accessed 10 Dec 2020

Wilkin P, Schols P, Chase MW, Chayamarit K, Furness CA, Huysmans S, et al. A plastid gene phylogeny of the yam genus, Dioscorea: roots, fruits and Madagascar. Syst Bot. 2005;30 (4):736-49.

Xiaoqin Z, Guolu L, Xiaolin L. A comparision among natural variations of Dioscorea zingiberensis. J Trop Subtrop Bot. 2003;11(3):267-70.

Zhang T, Hu Y, Jiang W, Fang L, Guan X, Chen J, et al. Sequencing of allotetraploid cotton (Gossypium hirsutum L. acc. TM-1) provides a resource for fiber improvement. Nat Biotechnol. 2015;33(5):531-7.

Zhang YM, Chen M, Sun L, Wang Y, Yin J, Liu J, et al. Genome-wide identification and evolutionary analysis of NBS-LRR genes from Dioscorea rotundata. Front Genet. 2020;11:484.

Open Access This chapter is licensed under the terms of the Creative Commons Attribution 4.0 International License (http://creativecommons.org/licenses/by/4.0/), which permits use, sharing, adaptation, distribution and reproduction in any medium or format, as long as you give appropriate credit to the original author(s) and the source, provide a link to the Creative Commons license and indicate if changes were made.

The images or other third party material in this chapter are included in the chapter's Creative Commons license, unless indicated otherwise in a credit line to the material. If material is not included in the chapter's Creative Commons license and your intended use is not permitted by statutory regulation or exceeds the permitted use, you will need to obtain permission directly from the copyright holder. 